U.S. Army
Coast Eng Res.

Ctr.

MR 82-14

\title{
Effects of Beach Nourishment and \\ Borrowing on Marine Organisms
}

by

Syed M. Naqvi and Edward J. Pullen

MISCELLANEOUS REPORT NO. 82-14
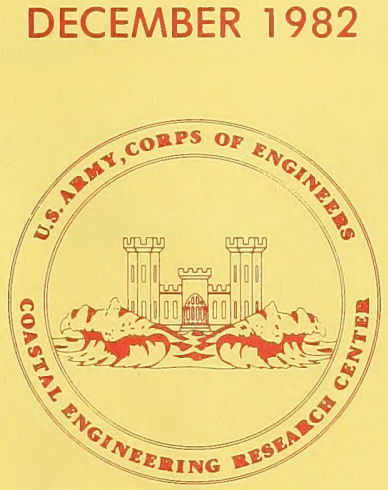

Approved for public release; distribution unlimited.

\section{U.S. ARMY, CORPS OF ENGINEERS COASTAL ENGINEERING RESEARCH CENTER \\ Kingman Building \\ Fort Belvoir, Va. 22060}

.0581

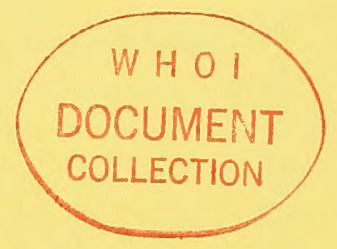

Miz \& $2-14$ 
Reprint or republication of any of this material shall give appropriate credit to the U.S. Army Coastal Engineering Research Center.

Limited free distribution within the United States of single copies of this publication has been made by this Center. Additional copies are available from:

\author{
National Technical Information Service \\ ATTN: Dperations Division \\ 5285 Port Royal Road \\ Springfield, Virginia 22161
}

The findings in this report are not to be construed as an official Department of the Army position unless so designated by other authorized documents.
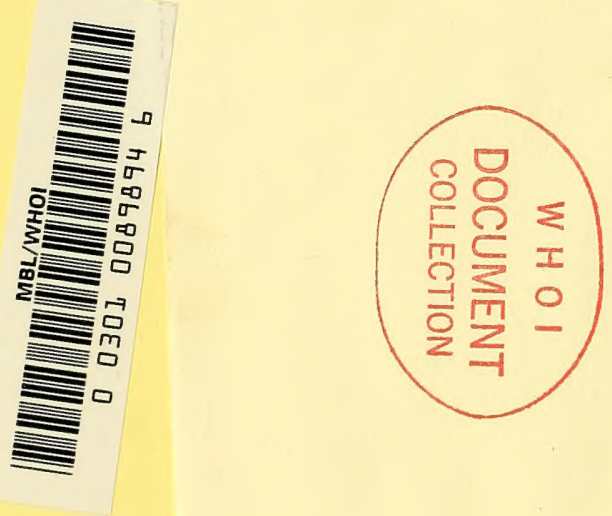


\begin{tabular}{|c|c|}
\hline REPORT DOCUMENTATION PAGE & $\begin{array}{l}\text { READ INSTRUCTIONS } \\
\text { BEFORE COMPLETING FORM }\end{array}$ \\
\hline 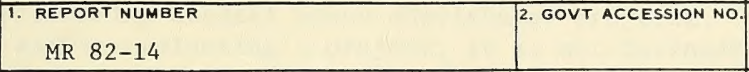 & 3. RECIPIENT'S CATALOG NUMBER \\
\hline $\begin{array}{l}\text { 4. TITLE (and Subttle) } \\
\text { EFFECTS OF BEACH NOURISHMENT AND }\end{array}$ & $\begin{array}{l}\text { 5. TYPE OF REPORT \& PERIOD COVERED } \\
\text { Miscellaneous Report }\end{array}$ \\
\hline BORROWING ON MARINE ORGANISMS & 6. PERFORMING ORG. REPORT NUMBER \\
\hline $\begin{array}{l}\text { 7. AUTHOR(s) } \\
\text { Syed M. Naqui } \\
\text { Edward J. Pullen }\end{array}$ & 8. CONTRACT OR GRANT NUMBER( $(\theta)$ \\
\hline $\begin{array}{l}\text { 9. PERFORMING ORGANIZATION NAME AND ADDRESS } \\
\text { Department of the Army } \\
\text { Coastal Engineering Research Center (CERRE-CE) } \\
\text { Kingman Building, Fort Belvoir, VA } 22060\end{array}$ & $\begin{array}{l}\text { 10. PROGRAM ELEMENT, PROJECT, TASK } \\
\text { AREA \& WORK UNIT NUMBERS } \\
\text { G31266 }\end{array}$ \\
\hline $\begin{array}{l}\text { 11. CONTROLLING OFFICE NAME AND ADDRESS } \\
\text { Department of the Army }\end{array}$ & $\begin{array}{l}\text { 12. REPORT DATE } \\
\text { December } 1982\end{array}$ \\
\hline $\begin{array}{l}\text { Coastal Engineering Research Center } \\
\text { Kingman Building, Fort Belvoir, VA } 22060\end{array}$ & $\begin{array}{l}\text { 13. NUMBER OF PAGES } \\
43\end{array}$ \\
\hline 14. MONITORING AGENCY NAME \& ADDRESS(II different from Controlling Office) & $\begin{array}{l}\text { 15. SECURITY CLASS. (of this roport) } \\
\text { UNCLASSIFIED }\end{array}$ \\
\hline & $\begin{array}{l}\text { 15a. DECLASSIFICATION/DOWNGRADING } \\
\text { SCHEDULE }\end{array}$ \\
\hline
\end{tabular}

Approved for public release; distribution unlimited.

17. DISTRIBUTION STATEMENT (of the abstract ontered in Block 20, if different from Report)

18. SUPPLEMENTARY NOTES

19. KEY WORDS (Continue on reverse alde If necessary and tdentity by block number)

$\begin{array}{ll}\text { Beach nourishment } & \text { Fish } \\ \text { Benthic communities } & \text { Impacts } \\ \text { Borrow areas } & \text { Sea turtles } \\ \text { Corals } & \end{array}$

20. AESTRACT (Cantinue an peverae afob if mececeary and fdontify by block number)

This report summarizes the latest research on the effects of beach nourishment and borrowing on the coastal environment. Guidelines are formulated for sampling the beach and nearshore, and recommendations for minimizing the impact of beach nourishment and borrowing are provided. 

This report is published to assist coastal managers in designing and implementing coastal beach nourishment projects. The report is to be used as an aid in evaluating a project; it is not intended to replace the studies needed to identify specific impacts that may be associated with nourishment and borrow operations. The work was carried out under the U.S. Army Coastal Engineering Research Center's (CERC) Ecological Effects of Beach Nourishment work unit, Environmental Impact Program, Environmental Quality Area of Civil Works Research and Development.

The report was prepared by Dr. Syed M. Naqvi, Southern University, Baton Rouge, Louisiana, and Edward J. Pullen, Chief, Coastal Ecology Branch, under the general supervision of Mr. R.P. Savage, Chief, Research Division, CERC. The material in this report is based on field studies supported by CERC and other literature sources.

Technical Director of CERC was Dr. Robert W. Whalin, P.E., upon publication of this report.

Comments on this publication are invited.

Approved for publication in accordance with Public Law 166, 79th Congress, approved 31 July 1945, as supplemented by Public Law 172, 88th Congress, approved 7 November 1963.

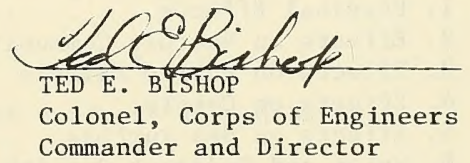


CONVERSION FACTORS, U.S. CUSTOMARY TO METRIC (SI) . . . . . . 6

GLOSSARY OF BIOLOGICAL TERMS . . . . . . . . . . . . 7

I INTRODUCTION . . . . . . . . . . . . . . . . . . 9

II BEACH AND NEARSHORE ENVIRONMENT . . . . . . . . . . . . . . 9

1. Beach Zone................... . . . 11

2. Surf Zone .................... . . . 11

3. Nearshore Zone ............... . . . 11

III BEACH AND NEARSHORE ORGANISMS . . . . . . . . . . . . . 11

1. Epifauna . . . . . . . . . . . . . . . . 12

2. Endofauna ................. . . . . . 12

3. Interstitial Fauna . . . . . . . . . . . 12

IV ADAPTATION OF BEACH AND NEARSHORE FAUNA . . . . . . . . . . . 12

V FEEDING STRATEGY ..................... . . . 13

VI SAMPLING THE BEACHES AND NEARSHORE . . . . . . . . . . . 13

1. Sampling Methods.................. 13

2. Sampling Plans.................. . . . . 13

3. Sampling Quality Assurance and Control ......... 17

4. Population Analysis . . . . . . . . . . . . . 18

5. Manpower Requirements ............. 18

VII EFFECTS OF BEACH NOURISHMENT . . . . . . . . . . . . 19

1. Physical Effects................. . . 19

2. Effects on Benthic Communities ........... . . 19

3. Effects on Motile Animals . . . . . . . . . . . . 20

4. Effects on Corals. . . . . . . . . . . . . . . . . . . . 21

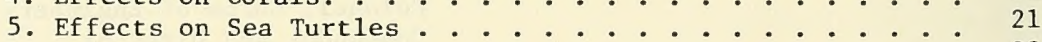

6. Water and Sediment Quality . . . . . . . . . . . . . . . . . 22

VIII FAUNAL RECOVERY OF NOURISHMENT SITES. . . . . . . . . . . . 23

1. Benthic Communities. . . . . . . . . . . . 23

2. Motile Animals ............... . . 24

3. Corals..................... . . . . 24

4. Sea Turtles ................ . . . 24

IX EFFECTS ON BORROWING . . . . . . . . . . . . . . . 24

1. Physical Effects... . . . . . . . . . . . 25

2. Effects on Benthic Communities . . . . . . . . . 25

3. Effects on Motile Animals. . . . . . . . . . . 26

4. Effects on Corals ................ . . 27

5. Effects on Sea Turtles... . . . . . . . . . . 28

6. Water and Sediment Quality . . . . . . . . . 28 
X FAUNAL RECOVERY OF BORROW PITS . . . . . . . . . . . . 29

1. Benthic Communities . . . . . . . . . . . 29

2. Motile Animals .. . . . . . . . . . . 30

3. Corals ................. . . . 30

4. Sea Turtles ................ . . 31

XI RECOMMENDATIONS . . . . . . . . . . . . . . . . 31

1. Beach Nourishment ............... 31

2. Borrowing . . . . . . . . . . . . . 32

XII SPECIAL RECOMMENDATIONS . . . . . . . . . . . . . 33

1. Coral Reefs.................. . . 33

2. Sea Turtles . . . . . . . . . . . . . . . 34

3. Fish . . . . . . . . . . . . . . . . 34

4. Clam Beds ................. 35

LITERATURE CITED . . . . . . . . . . . . . 36

APPENDIX REFERENCES RELATED TO THE DIRECT AND INDIRECT EFFECTS OF

BEACH NOURISHMENT AND BORROWING . . . . . . . . . . . . . . . .

FIGURES

1 Beach nourishment operation, Mayport, Florida . . . . . . . . . 10

2 High-energy sand beach system . . . . . . . . . . . . . 10

3 Core sampling at sandy-bottom stations . . . . . . . . . . . . . . 14

4 Diver using lifeline in surf . . . . . . . . . . . . . . . 15

5 Quadrat sampling at reef stations . . . . . . . . . . . . . 16

6 Reef fauna near outer edge of second reef off Golden Beach,

Florida . . . . . . . . . . . . . . . . . . . . .

7 Nesting sea turtle... . . . . . . . . . . . . . . 
CONVERSION FACTORS, U、S. CUSTOMARY TO METRIC (SI) UNITS OF MEASUREMENT

U.S. customary units of measurement used in this report can be converted to metric (SI) units as follows:

\begin{tabular}{|c|c|c|}
\hline Multiply & by & To obtain \\
\hline $\begin{array}{l}\text { inches } \\
\text { square inches } \\
\text { cubic inches }\end{array}$ & $\begin{array}{l}25.4 \\
2.54 \\
6.452 \\
16.39\end{array}$ & $\begin{array}{l}\text { millimeters } \\
\text { centimeters } \\
\text { square centimeters } \\
\text { cubic centimeters }\end{array}$ \\
\hline $\begin{array}{l}\text { feet } \\
\text { square feet } \\
\text { cubic feet }\end{array}$ & $\begin{array}{l}30.48 \\
0.3048 \\
0.0929 \\
0.0283\end{array}$ & $\begin{array}{l}\text { centimeters } \\
\text { meters } \\
\text { square meters } \\
\text { cubic meters }\end{array}$ \\
\hline $\begin{array}{l}\text { yards } \\
\text { square yards } \\
\text { cubic yards }\end{array}$ & $\begin{array}{l}0.9144 \\
0.836 \\
0.7646\end{array}$ & $\begin{array}{l}\text { meters } \\
\text { square meters } \\
\text { cubic meters }\end{array}$ \\
\hline $\begin{array}{l}\text { miles } \\
\text { square miles }\end{array}$ & $\begin{array}{l}1.6093 \\
259.0\end{array}$ & $\begin{array}{r}\text { kilometers } \\
\text { hectares }\end{array}$ \\
\hline knots & 1.852 & kilometers per hour \\
\hline acres & 0.4047 & hectares \\
\hline foot-pounds & 1.3558 & newton meters \\
\hline millibars & $1.0197 \times 10^{-3}$ & kilograms per square centimeter \\
\hline ounces & $28 \cdot 35$ & grams \\
\hline pounds & $\begin{array}{l}453.6 \\
0.4536\end{array}$ & $\begin{array}{l}\text { grams } \\
\text { kilograms }\end{array}$ \\
\hline ton, long & 1.0160 & metric tons \\
\hline ton, short & 0.9072 & metric tons \\
\hline degrees (angle) & 0.01745 & radians \\
\hline Fahrenheit degrees & $5 / 9$ & Celsius degrees or Kelvins 1 \\
\hline
\end{tabular}

${ }^{1}$ To obtain Celsius (C) temperature readings from Fahrenheit (F) readings, use formula: $C=(5 / 9)(F-32)$.

To obtain Kelvin $(K)$ readings, use formula: $K=(5 / 9)(F-32)+273.15$. 
ANAEROBIC DECOMPOSITION - Substances are reduced, not oxidized, because of lack of oxygen.

ANOXIA - The failure of oxygen to gain access to, or to be utilized by, the body tissue.

BENTHIC ORGANISMS - Bottom organisms attached or resting on or in the bottom sediments.

CARRION - Dead and putrefying flesh.

CHEMOAUTOTROPHIC - A process by which organisms manufacture their food by using the energy derived by oxidizing inorganic matter.

DEMERSAL - Organisms (usually fish) that live on or slightly above the bottom.

DIATOM - Organisms closely associated with algae, characterized by the presence of silica in the cell walls.

ECOLOGICAL PERTURBANCE - Disturbance of natural habitat of animals and plants due to natural or artificial means.

EDAPHIC - A term referring to the soil conditions or types as ecologica1 factors.

ENDOFAUNA - Animals whose biological activities are restricted within the sediment.

EPIFAUNA - Animals that live on or above the sand surface.

FALSE CRAWL - When a turtle crawls onto a beach and does not attempt to nest or fails to excavate a nesting chamber and deposit its eggs.

FAUNA - The entire animal life of a region.

HARD CORAL - Nonflexible corals.

INTERSTITIAL - A term referring to the space between particles.

LUCUNA - Smal1 space or environment.

MACROFAUNA - Those animals 0.5 millimeter or larger in size.

MEIOFAUNA - Those animals smaller than 0.5 millimeter and equal to or larger than 0.062 millimeter.

MESOFAUNA - Animals that live between the interstices of sediment particles. NEKTON - Free-swimming organism.

OPPORTUNISTIC SPECIES - Short-lived species that invade an area but are generally out competed by resident species. 
OXIDATION-REDUCTION - A chemical reaction on which one or more electrons are transferred from one atom or molecule to another.

PELAGIC - All ocean waters covering the benthic region.

PHOTOAUTOTROPHIC - A process by which organisms manufacture their food by light.

POLYPS - An individual sessile, coelenterate.

ROSE BENGAL DYE - A bluish-red acid dye used as a biological stain to aid in sorting the animals from the sediment.

SOFT CORAL - Flexible corals, i.e., gorgonians, sea whips, and sea fans.

STONY CORAL - Hard corals, i.e., brain coral (Monastrea carvemosa) and staghorn coral (Acropora cemicomis).

TAXON - Name applied to a taxonomic group.

TROPHIC - A successive stage of nourishment as represented by links through the food chain beginning with the primary producers and continuing through the carnivores.

ZOOXANTHELLAE - Symbiotic algae. 


\author{
by \\ Syed M. Naqvi and Edward J. Pullen
}

\title{
I. INTRODUCTION
}

Shore erosion is a major problem along the U.S. east and west coasts and along the Great Lakes, resulting in significant property damage, the loss of land, and the loss of recreational beaches. Beach nourishment with dredged material can provide a means of counteracting beach erosion in some coastal areas. This is generally done by borrowing sediment material from offshore or inshore locations and pumping the material to an eroding beach (Fig. 1). However, a massive displacement of the substratum can inadvertently disturb the fauna and the topography of borrow and nourishment areas. Such an ecological perturbation can extensively damage benthic nonmotile communities (i.e., corals and clams) or cause habitat alterations (i.e., for sea turtles and fish). A well-planned nourishment operation is important to minimize the ecological effects, and may even be beneficial for certain marine animals, if environmental conditions are favorable.

This report summarizes the results of the latest research on effects of beach nourishment and borrowing on coastal ecology. Based on experimental and field studies, recommendations have been formulated especially for the benefit of the coastal manager. It is emphasized, however, that physical and biological conditions tend to vary from one geographical region to the next. Therefore, strict compliance to these recommendations may not be feasible in a11 situations.

\section{BEACH AND NEARSHORE ENVIRONMENT}

A coastal beach system includes the unvegetated part of the sandy shoreline and the submerged nearshore area (Fig. 2). Ecologically, the beach system is a specialized environment occupied by those animals that have the capacity to adapt to the regular displacement of sediments. The coastal beach system is generally in a state of dynamic equilibrium, continually shifting in response to waves, winds, currents, and tides. Each part of the beach is capable of receiving, storing, and losing sand. This depends on the constantly changing natural forces.

Sandy beaches provide a unique habitat for burrowing animals which represent the majority of the invertebrate fauna. Several vertebrates have also become an integral part of beach fauna. Fish, birds, and reptiles use the beach for spawning, breeding, nesting, feeding, or just resting. There are also other animals that are occasional visitors to the coastal beaches, e.g., the sea turtles including the threatened loggerhead (Caretta caretta) and the endangered green turtles (Chelonia mydas) (Fletemeyer, 1980). In addition, the shallow waters of the nearshore zone provide an excellent habitat for a variety of shellfish and forage fish which, in turn, attract predatory birds, fish, and man. 


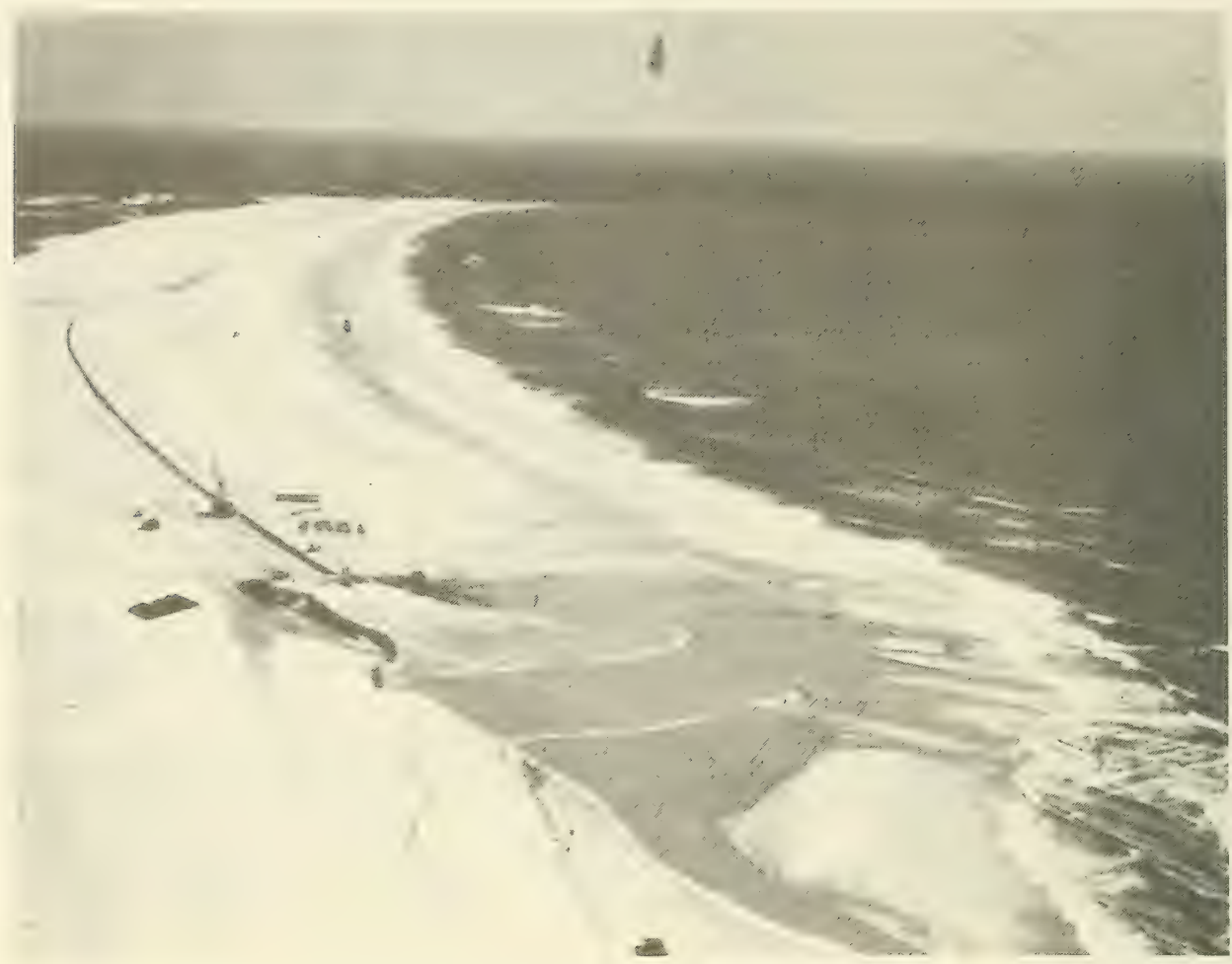

Figure 1. Beach nourishment operation, Mayport, Florida (courtesy of U.S. Army Engineer District, Jacksonville).

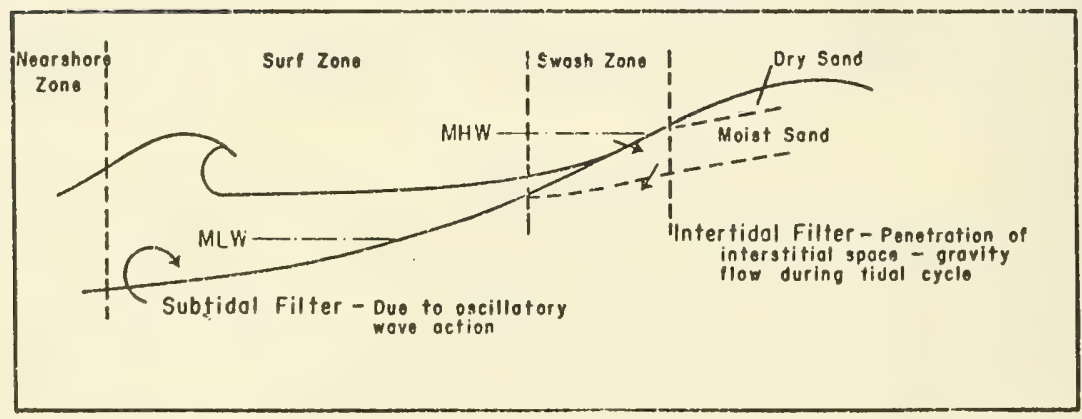

Figure 2. High-energy sand beach system (modified from Cox, 1976). 
The beach system is divided into three zones based on the physical environment and associated resident inhabitants: the beach, surf, and nearshore zones (Fig. 2).

\section{Beach Zone.}

The beach is the zone of unconsolidated material that extends landward from the low water line to the foredune line. It is an area subject to harsh environmental and physical changes, including a wide temperature range, salinity fluctuations, and wave action that causes cycles of erosion and accretion. The upper beach (above mean high water, MHW) is generally dry except during storms. Storms can significantly modify the physical environment by eroding or accreting the upper beach and altering the beach animal communities. Because of this surface environment most of the permanent residents of the upper beach are burrowers. The number of species and the population size on the upper beach are limited; the organisms generally have a patchy distribution. Resident species of the upper beach generally emerge from their burrows only at night. Characteristic species are ghost crabs (Ocypode) and sandfleas (Talitridae). The lower beach (below MHW) also has a paucity of species, but usually large numbers of individuals. The lower beach is characterized by worms (annelids), clams (Donax), and mole crabs (Emerita). Plant production on a high-energy beach is generally low, but may include blue-green algae and diatoms.

\section{Surf Zone.}

The surf zone is the area of breaking waves; it varies in location and size. Seasonal wave patterns, sediment movement, and storms are major physical forces that influence the distribution and abundance of animals in this zone. Most of the benthic animals in the surf are burrowers and good diggers, which are excellent characteristics to maintain position in the bottom. Benthic animal populations are generally small with a clustered distribution. As an adaptation to this unstable environment, intertidal benthic organisms tend to have a short life cycle ( 1 to 2 years) and a high rate of reproduction (Marsh, et al., 1980). The nektonic and benthic animals that reside in the surf are limited by wave action, lack of cover, and food supply. Some of the animals migrate onshore and offshore with the tides and seasonal sediment movement.

\section{Nearshore Zone.}

The nearshore zone extends seaward of the surf zone. This is physically a more stable environment than the beach or surf zone, and the fish and benthic animal populations are also stable and diverse. This zone has the greatest abundance of commercial and sport fish and shellfish, and is the most susceptible to physical perturbation. Nearshore organisms are generally less subject to impacts of waves and natural sediment movement than those in the surf zone.

\section{BEACH AND NEARSHORE ORGANISMS}

A sandy beach system, despite its uniform appearance, harbors a fauna of great ecological diversity. The beach system offers space for three main types of populations: the epifauna and endofauna which live on, above, and 
in the substratum and the interstitial fauna which live between the sand particles of the porous sediment (the middle region).

\section{Epifauna.}

The epifauna live on or above the sand surface. Considering species diversity, this group represents the smallest number of animals associated with the beaches, but it is the major group linking the marine and terrestrial species. Reduced species diversity of epifauna on the high-energy beaches is probable because: (a) shifting sand is inhospitable to many animals that need stable conditions or protection; and (b) only the larger animals that are strong and fast enough to keep up with the waves and currents are able to compete with the dynamic conditions. Consequently, these larger forms establish the highest level in the food chain in the surf and beach zones and are generally relatively few.

\section{Endofauna.}

The endofauna include those species whose biological activities are restricted within the sand. Based on size, animals of this group are divided into macrofauna (animals retained by a 0.5 -millimeter mesh screen) and meiofauna (animals that pass through a 0.5-millimeter mesh screen and are retained by a $0.062-\mathrm{millimeter}$ mesh screen). In areas of heavy wave activity, the endofauna are generally limited to the robust and quickly moving species. Therefore, on high-energy beaches, stationary or semisedentary forms are generally scarce. The endofauna on most sandy beaches are dominated by crustaceans, mollusks (clams) and polychaetes (worms).

\section{Interstitial Fauna.}

This group includes the meiofauna and microfauna (animals smaller than 0.062 millimeter) that have the ability to live within the interstitial space of sand grains. They include a greater diversity of species than the epifauna and endofauna. These organisms are known to be highly sensitive to the slightest changes in edaphic conditions, which correspond to differences in the hydrodynamic forces. The dominant interstitial fauna found in the intertidal environment are protozoans (ciliates and foraminiferans), turbellarians (flatworms), nematode (roundworms), gastrotrichs, and harpacticoid copepods

(crustaceans). The vertical distribution of many of these organisms in a sandy beach varies with season of the year; a migration toward greater depths occurs during the cooler seasons. Fenchel (1969) described the distribution of interstitial fauna as related to oxidation-reduction properties of the sediment and its mechanical composition.

\section{ADAPTATION OF BEACH AND NEARSHORE FAUNA}

Animals that live in shifting sands on marine beaches are well adapted to the unusual conditions of their existence and tolerate various environmental factors in order to feed, burrow, and reproduce. Many sand dwellers endure periods of low oxygen levels, and large animals that live deep in burrows have the capability to create respiratory currents. These animals are adapted to withstand the beating and pulling actions of waves and currents. Some are skillful burrowers that dig in quickly when exposed by the waves. Many of the beach animals withstand desiccation and do not die when left exposed on the 
beach. Motile species such as fish, crabs, and shrimp are also able to survive in the area of breaking waves in the surf.

\section{FEEDING STRATEGY}

Generally the feeding categories of high-energy beaches include grazers, filter feeders, and predators-scavengers. Many sand-dwelling benthic animals are adapted to feeding on bacteria, algae, diatom, and other micro-organisms by grazing and filter feeding. There are also numerous scavengers and predator species, ranging from protozoans to fishes. Leber (1977), Reilly and Bellis (1978), and Modde (1980) observed that many fish and shellfish feed in the surf. The beach is an open system whose main exchange is with the ocean by inputting organics and carrion and outputting nutrients and beach organisms (McLachlan, et a1., 1981).

\section{SAMPLING THE BEACHES AND NEARSHORE}

1. Sampling Methods.

There have been few quantitative studies on the effects of beach nourishment on marine communities along the high-energy coastal beaches because these beaches are difficult and hazardous to sample. The Coastal Engineering Research Center (CERC) recently published a report which provides a standardized system for sampling macroinvertebrates on high-energy sand beaches (Hurme, Yancey, and Pullen, 1979). The report suggests that samples on the upper beach be taken by excavating 0.1 -square meter quadrats with a trench shovel and sieving the samples through a 0.5-millimeter mesh soil sieve. In the surf zone, a coring device assures a better sample than do other types of equipment. Offshore of the surf zone, cores, grabs, and dredges may be used. Cores taken by a diver give the best and most consistent samples (Fig. 3). Trawls and beach seines are less quantitative, but they provide samples that are useful in interpreting biological changes that are not detectable in the core and dredge samples.

When working in the surf, the investigator should use a lifeline to stay on station (Fig. 4); range markers on the beach are also helpful for keeping divers on station. Samples are generally collected along lines or transects perpendicular to the beach and are stored in plastic bags, labeled, and preserved. Sorting of the animals from the sediments is done on the beach or in the laboratory. The animals preserved are later identified and counted.

In clear water, diver observations and photos provide valuable information that supplements core samples. Divers can observe and count attached reef animals (Fig. 5), burrowing and reef fish which tend to be territorial, and pelagic fish (Fig. 6).

\section{Sampling Plans.}

Sampling plans for a specific area depend on the nature and magnitude of the project, the use and purpose of the data, and on the animals to be evaluated. The animals may be fixed or motile with populations that vary seasonally and distributions that are random or clustered. Knowledge of this information on the study area and on the animals is necessary to determine the required sampling equipment, sampling frequency, number of samples, and number of stations needed. The length of a study will vary depending on the time 


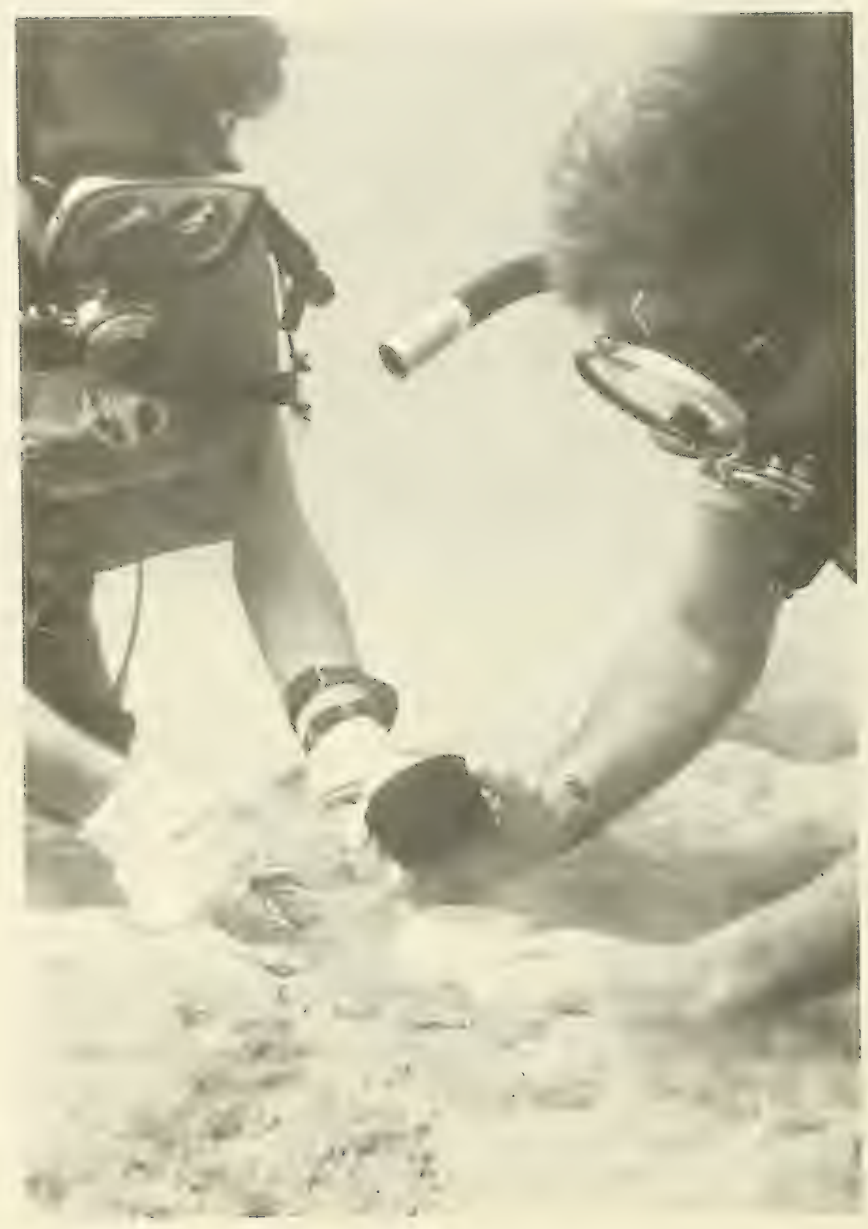

Figure 3. Core sampling at sandy-bottom stations (Turbeville and Marsh, 1982). 


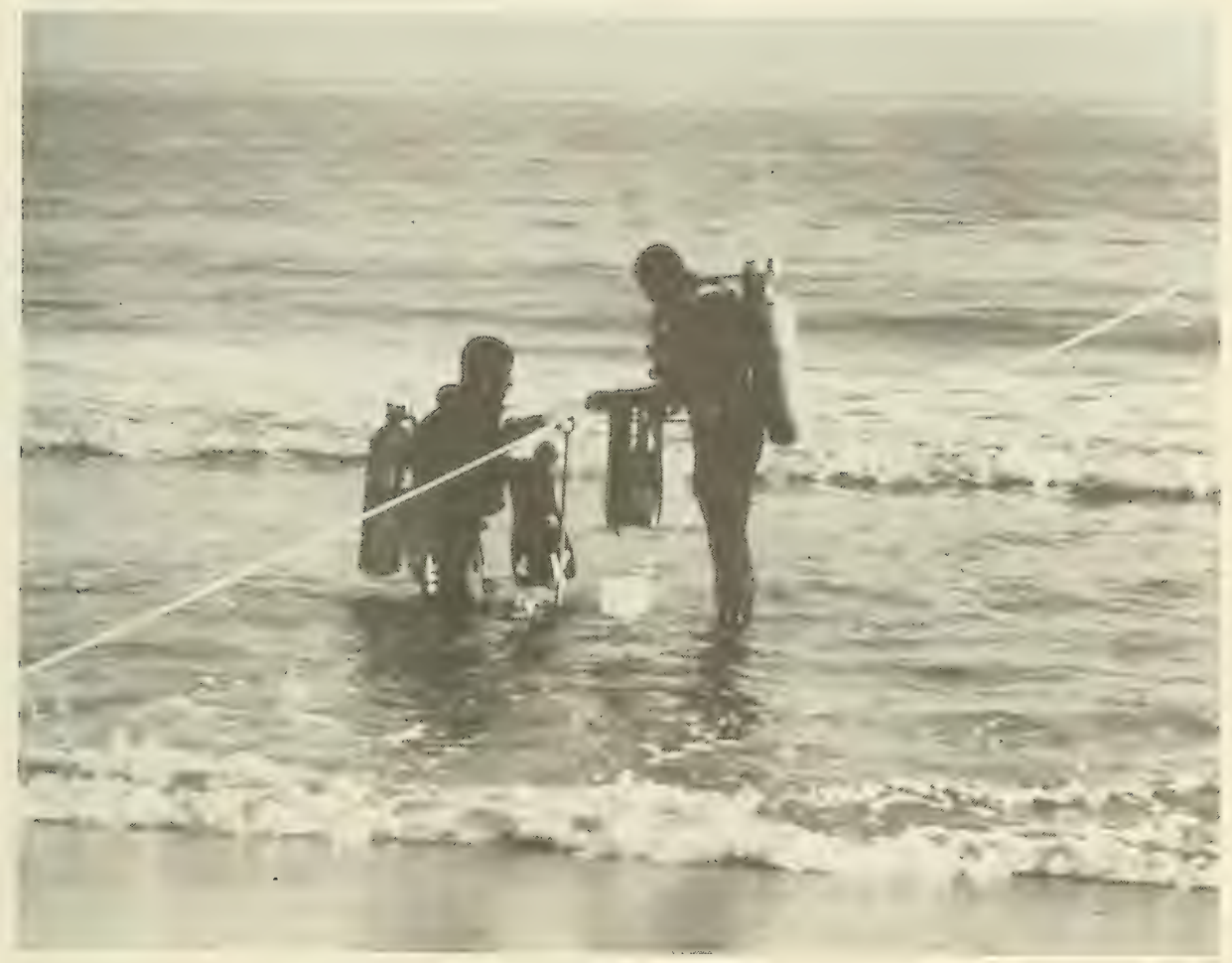

Figure 4. Diver using lifeline in surf. 


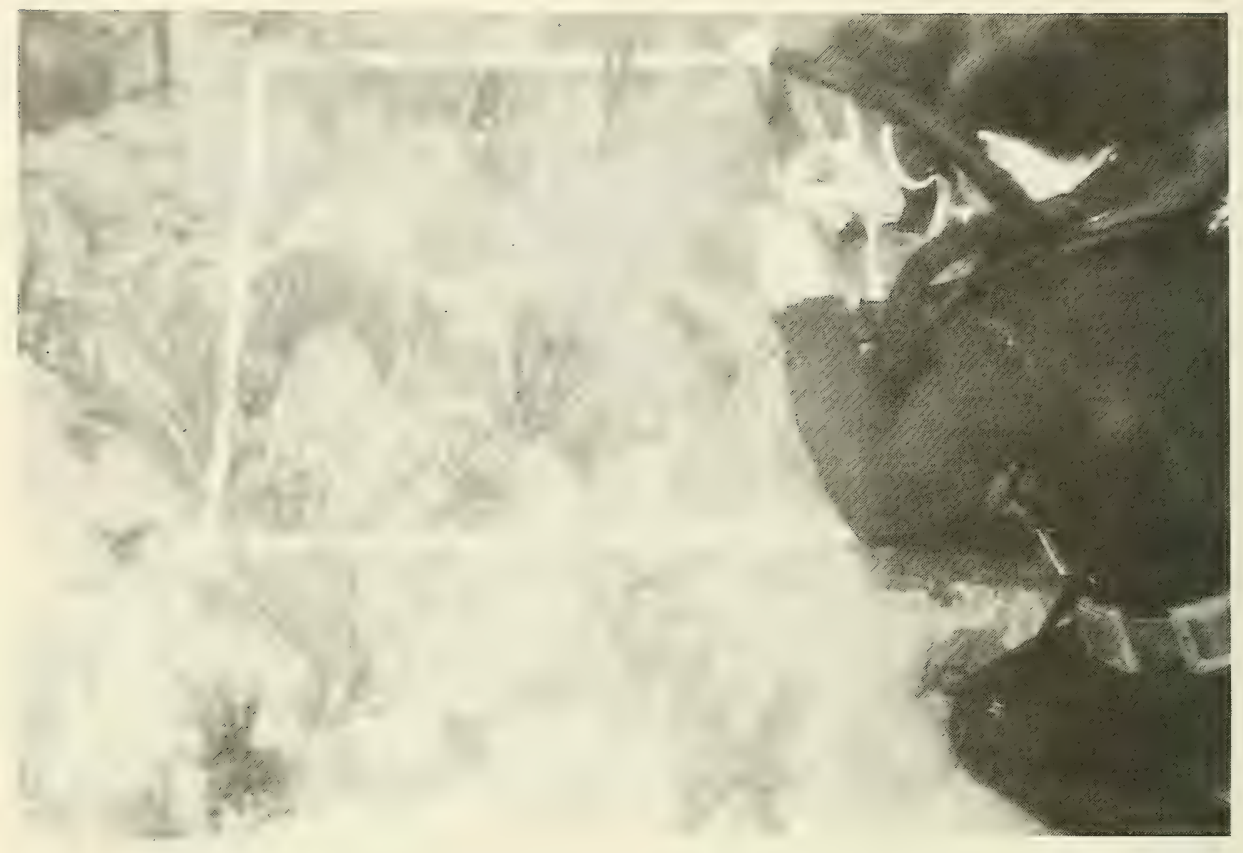

Figure 5. Quadrat sampling at reef stations (Marsh, et al., 1980). 


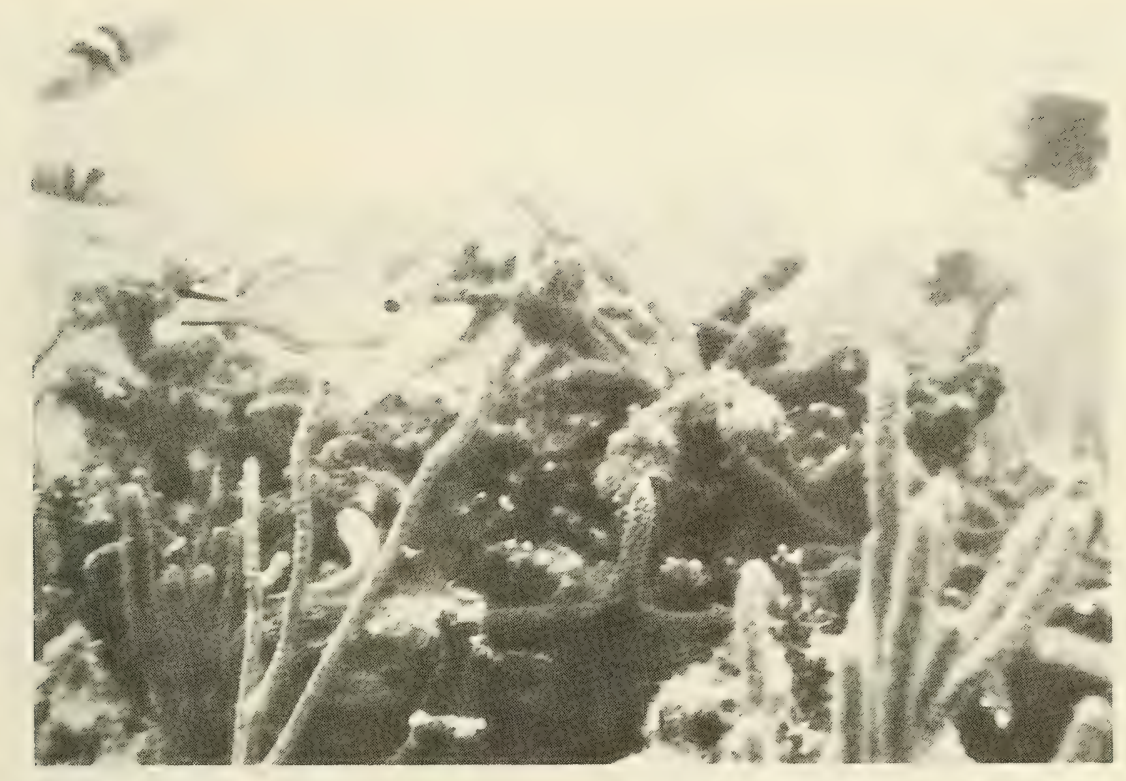

Figure 6. Reef fauna near outer edge of second reef off Golden Beach, Florida (Courtenay, Hartig, and Loisel, 1980).

required to determine base-line conditions prior to beach nourishment and the time required for animal populations to stabilize following nourishment.

\section{Sampling Quality Assurance and Control.}

The accuracy and adequacy of the data collected and the validity of the data analysis will depend on the study design. The following sampling guidance is suggested to aid in designing a study to properly assess the environmental impact of beach nourishment.

(a) The sampling device should be reliable and accurate. It should insure consistent substrate penetration, no loss of sample during retrieval, and least variation between sample size. Refer to Menzies and Rowe (1968), Holme and McIntyre (1971), and Hurme, Yancey, and Pullen (1979) for descriptions of sampling devices.

(b) Sieve size for sorting benthic animals should be accurate to allow passage of meiofauna and retention of macrofauna (Reish, 1959; Hurme, Yancey, and Pullen, 1979). Studies have shown that a 0.5-millimeter mesh sieve is desirable for quantitative macrobenthic collections.

(c) The procedures for animal preservation should be consistent. Animals stored in the field should be preserved with a buffered 10 percent 
formalin-seawater solution stained with rose bengal. If stored for a period of time greater than 3 months, the benthic samples should be transferred to 70 percent isopropyl alcohol. After identification and numeration, reference samples should be stored in 70 percent isopropyl alcohol.

(d) The number and the locations of stations should be chosen carefully before the project begins. Addition and deletion of stations should be avoided as much as possible. The number of stations should be adequate to address spatial variability of fauna.

(e) Replications should be adequate (1) to account for variability within station fauna, and (2) to collect the majority of the species inhabiting the operation site. Refer to Hurme, Yancey, and Pullen (1979) to determine the number of replicate samples required.

(f) There should be a sufficient temporal frequency of sampling to address seasonal variation in the physical and biological parameters; at least seasonal sampling is recommended.

(g) Sampling methods for "pre," "post," and "during" operations should be consistent and comparable.

(h) Identification of organisms should be confirmed by an expert for each taxonomic group. New or undescribed species should also be sent to a specialist for further confirmation or identification.

(i) Consistency in all data analysis (methods, designs) should be maintained.

(j) Planning of the fieldwork, timing of the field trips, and devising the sampling plan should be carefully done (hurme, Yancey, and Pullen, 1979).

4. Population Analysis.

The level of reliability of population analysis depends on the quantitative accuracy of the samples. Good quantitative data collected before, during, and after beach nourishment can be analyzed for changes in species diversity, abundance, and biomass using valid statistical approaches. This type data can be used in evaluating recolonization after a disturbance. Several commonly used statistics are discussed by Hurme, Yancey, and Pullen (1979).

\section{Manpower Requirements.}

Manpower estimated for collecting, processing, and analyzing benthic data varies depending on the location of sampling, site conditions and size, number and type samples to be taken, the size of animals collected (macrobenthos or meiobenthos), and the level of taxonomic identification. As a general rule, project time for an assessment can be prorated as follows: field time, 10 to 25 percent; sample processing, 50 to 75 percent; data analysis, 5 to 10 percent; and preparation of an assessment document, 10 to 20 percent. Sorting (or picking) macrobenthic samples generally takes 1 to 4 hours per sample depending on whether or not the sediment is fine or coarse. Processing time, 
which includes taxonomic identification, varies from 1 to 4 hours for beach samples with 25 to 75 species and 6 to 10 hours for nearshore samples with 200 to 300 species (Dr. R. Diaz, Virginia Institute of Marine Science, personal communication, May 1981).

\section{EFFECTS OF BEACH NOURISHMENT}

Recent studies have demonstrated that beach nourishment activities may be detrimental, beneficial, or have no marked effect on the fauna, depending on the local situation. The Appendix provides a listing of the most recent reports on different aspects of beach nourishment and associated borrowing indicated by reference numbers in the Literature Cited. Hajor conclusions from these reports have been included in the current report to aid the manager in visualizing the possible effects of such a project.

\section{Physical Effects.}

There are three major ways that beach nourishment physically impacts the beach environment; the deposited material covers the existing beach sediments, modifies the beach interface, and frequently increases the turbidity of the nearshore area (Fig. 1). Waves and currents winnow and suspend sediments in the water along a nourished beach, increasing the turbidity of the water. Parr, Diener, and Lacy (1978) observed at Imperial Beach, California, that the fine sediments were rapidly sorted out of deposited material and that sediment grain-size distribution after about 4 months was comparable to that before nourishment. The fine sediments were transported offshore. Courtenay, Hartig, and Loisel (1980) also observed sediments that lodged against and partly covered low profile coral reefs off the Florida east coast. Regardless of origin, sediment movement and changes in grain-size distribution may create a benthic environment that requires marine organisms to adjust or perish. Pearson and Riggs (1981) stated the critical importance of matching nourishment material to the hydraulic energies of the beach. Placed material that is not in equilibrium will erode to offshore areas.

Turbidities resulting from beach nourishment generally create only a minor impact in the surf and offshore zones, except in areas of environmentally sensitive resources that easily smother or are dependent on light for photosynthesis.

\section{Effects on Benthic Communities.}

The marine bottom communities on most high-energy coastal beaches survive periodic changes related to the natural erosion and accretion cycles and storms. However, nearshore communities are in a more stable environment and are less adaptable to such perturbations. Direct burial of beach nourishment material on nonmotile forms would be generally lethal, while motile animals might escape injury. Some infaunal bivalves and crustaceans can migrate vertically through the sediments. Maurer, et a1. (1978) observed in a laboratory experiment that some benthic animals are able to migrate vertically through more than 30 centimeters of sediment. However, their survival depends not only on the sediment depth, but also on length of burial time, season, particlesize distribution, and other habitat requirements of the animal. 
Reilly and Bellis (1978) reported extensive damage to amphipods and other benthic animals due to a nourishment operation in North Carolina. Hayden and Dolan (1974) observed a redistribution of mole crabs at a North Carolina beach, but no mortalities because of nourishment. Taylor Biological Company (1978) also observed no long-term faunal damage 4 years after beach nourishment at Treasure Island, Florida. Culter and Mahadevan (1982) observed no long-term damage to the macrofauna 6 years after beach nourishment at Panama City Beach, Florida. Marsh, et al. (1980) found no observable lasting effect on the macrofauna 7 years after beach nourishment at Hallandale Beach, Florida.

Dredge and fill operations have caused faunal enrichment expressed as diversity and increased number of species. This in many cases is related to opportunistic species invading an area following a disturbance which are later replaced by resident species. Parr, Diener, and Lacy (1978) noted the effects of beach nourishment at Imperial Beach, California, were short term (5 weeks or less), involving an increase in abundance of motile crustaceans. Applied Biology, Inc. (1979) observed an increase in macrobenthic populations following nourishment at Duval County, Florida. Faunal enrichment following a disturbance was also recorded earlier by Clark (1969) and Gustafson (1972).

Meiobenthic animals are more susceptible to the effect of dredging. Rogers and Darnell (1973) recorded more than 50 percent meiofaunal reduction due to a dredging operation in Texas. Sherman and Coul1 (1980) simulated dredging by manually disturbing the sediments of a 9-square meter area and recorded more than 70 percent reduction in the meiofauna population. Pequegnat (1975) also observed a decrease in meiofauna population related to dredging activities. It is questionable, however, if these results can be extrapolated to a beach nourishment situation. It appears from these studies that meiobenthic animals are more sensitive to disturbances than macrobenthic animals and it takes longer for their populations to recover.

3. Effects on Motile Animals.

Mobility of fishes and some invertebrates render them least vulnerable to adverse effects of beach nourishment. However, decimation of food-chain organisms by heavy deposition of sediment would indirectly affect their populations. Bottom-feeding and bottom-dwelling fishes (e.g., flounder) would be most likely affected. Suspended solids in the water can affect the fish populations by delaying hatching time of fish eggs (Schubel and Wang, 1973), killing the fish by coating their gills, and by anoxia ( $0^{\prime}$ Connor, Neumann, and Sherk, 1976). Fish tolerance to suspended solids varies from species to species by age (Boehmer and Sleight, 1975; 0'Connor, Neumann, and Sherk, 1976). Generally, filter feeders are less tolerant to siltation than bottom feeders (Sherk, O'Connor, and Neumann, 1974).

Destruction of habitat rather than suspension of sediments seems to be the major danger to beach and nearshore fish. Most of these animals have the ability to migrate from an undesirable environment and reappear when disposal ceases (O'Connor, Neumann, and Sherk, 1976; Courtenay, Hartig, and Loisel, 1980). Species which are closely associated with the beach for some part of their life cycle, such as the grunion (Leuresthes tenuis) on the west coast and some burrowing and reef fish with limited mobility on the Florida coast, are most likely affected by beach nourishment. Parr, Diener, and Lacy (1978) observed that beach nourishment did not prevent subsequent spawning of grunion at 
Imperial Beach, California. However, the dusky jawfish (Opistognathus whitehursti), a burrowing species with a limited power of mobility and a requirement for a certain sand grain size, was displaced by fine sediments on the Florida east coast (Courtenay, Hartig, and Loisel, 1980).

The loss of a food source by burial of nourishment sediments will have some effect on motile populations, but this has not been demonstrated to be of major significance. However, there has been evidence that nourishment may benefit fish by suspending food material (Courtenay, et al., 1972) and associated turbidities may provide temporary protection from predators (Harper, 1973). Fishes have also been attracted to dredging operations in Florida (Ingle, 1952) and Louisiana (Viosca, 1958) and sand mining operations in Hawaii (Maragos, et al., 1977).

\section{Effects on Corals.}

Corals are sensitive to covering by fine sediments. The hard corals are more sensitive than the soft corals because they are unable to cleanse themselves of heavy sediment loads and are easily smothered. The soft corals are better adapted for survival in the nearshore areas subject to beach nourishment.

Coral damage as a result of beach nourishment is usually caused by excessive sedimentation and by direct physical damage to a reef. Sedimentation may inhibit the food-acquiring capability of polyps, eventually killing the coral, and inhibit protosynthesis of symbiotic green algae (Zooxanthellae) (Goldberg, 1970; Courtenay, et al., 1972). Both are essential for the survival of the coral.

On the other hand, studies have shown that coral reefs are not totally fragile and that they can withstand some sedimentation. Courtenay, et al. (1974) studied the effects of beach nourishment on nearshore reefs at Hallandale Beach, Florida. They noted that the reefs sustained damage caused by fine materials eroding from the nourished beach. Seven years later Courtenay, Hartig, and Loisel (1980) and Marsh, et a1. (1980) resurveyed the reefs and found no evidence of major reef damage.

\section{Effects on Sea Turtles.}

Sea turtle nesting and beach nourishment operations conflict in many coastal areas, particularly along the Florida coast (Fig. 7). Beach nourishment may inhibit or reduce turtle nesting and hatching success by altering their habitat (Mann, 1977; Fletemeyer, 1978, 1979, 1980). Hendrickson and Balasingham (1966) found that the sand particle size affected nest selection by leatherback turtles (Dermochelys coriacea). Fletemeyer $(1978,1979,1980)$ also determined compaction of sand to be important for nest selection by Loggerhead turtles. The same author reported a higher number of "false crawls" on two of the six nourished beaches in Florida. The effects of beach nourishment on sea turtles are inconclusive due to lack of adequate data, but the studies do indicate caution should be taken in nourishing turtle-nesting beaches. If it is determined that a project will affect sea turtles, U.S. Fish and Wildlife Service, National Marine Fisheries Service, and turtle experts should be consulted to develop a plan that will minimize the impact of beach nourishment. Adverse effects may also be avoided by the proper timing of the operation to not conflict with turtle nesting during the spring and summer (April to September). 


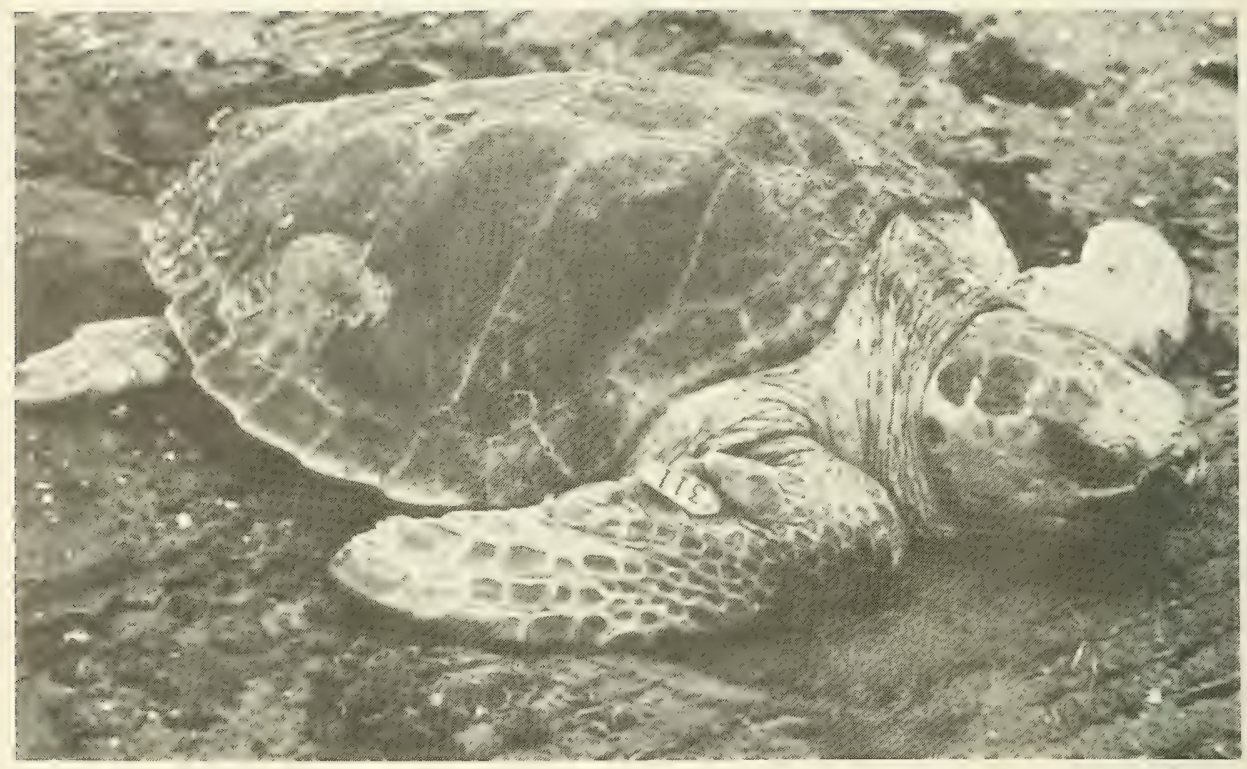

Figure 7. Nesting sea turtle.

\section{Water and Sediment Quality.}

Problems with anoxic sediments and nutrient release in the nearshore zone of a high-energy beach as a result of beach nourishment do not appear to be major because the fine materials that are high in organics are generally moved offshore and sulfides are rapidly oxidized. The material remaining on the beach is usually similar or larger in grain size to that before nourishment. High-energy beaches are usually composed of coarse material that allows oxygenated water to penetrate, preventing the accumulation of sulfides and saturating the sediment pore space with oxygen (Cox, 1976). Although some nutrients may be released into the water as a result of nourishing the beach, they are usually rapidly diluted because of the mixing process. Reilly and Bellis (1978) reported on the use of dredged material from a navigation channel that contained fine material and clay high in organics for beach nourishment. They noted that the release of the fine sediments from the beach temporarily inhibited the reestablishment of the beach macrofauna. However, CERC's studies of using nourishment materials from offshore that is similar to the beach sediments did not find these problems with suspended sediments, anoxic sediment, or excess nutrients. To minimize potential problems, sediments used for beach nourishment should closely match the composition of the natural beach sediments, have a low percentage of fine material, and be low in organic content. McLachlan, et al. (1981) cautioned that because of the species richness of the beach environment and the cellular circulation patterns nearshore, the beach system may be more sensitive to effluents than is readily apparent. 
The time required for faunal recovery following beach nourishment varies and is difficult to predict because of natural variations in biotic and abiotic factors. Natural perturbances (storms) and normal population fluctuations (seasonal and nonseasonal) can cause abrupt changes in physical, chemical, and biological conditions of an area. These natural fluctuations in undisturbed coastal environments and their biotic populations can be so great that it is difficult to detect effects of human activities or recovery time of a biotic system (Maurer, et a1., 1979). Studies applicable to fauna recovery should be carefully designed and extend at least 2 or more years for their seasonal and nonseasonal fluctuations to be adequately considered in analyzing the impact of a manmade disturbance.

\section{Benthic Communities.}

Recovery of macrobenthic animals varies and differs from one site to another. Reilly and Bellis (1978) and Parr, Diener, and Lacy (1978) noted that when nourishment ceases, the recovery of the macrofauna is rapid and complete recovery might occur within one or two seasons. Saloman (1974), Taylor Biological Company (1978), Marsh, et al. (1980), and Culter and Mahadevan (1982) also support the view that macrofauna will recover rapidly after ecological perturbations. Tropical Biological Industries (1979) predicted the normal macrofaunal recovery to be about 5 to 6 weeks following beach nourishment. Recovery will depend on the season of the year of the nourishment operation and the recruitment of larval fauna. The ability of the macrofauna to recover rapidly is due to (a) their short life cycles, (b) their fast reproductive potential, and (c) the recruitment of plankton larvae and motile macrofauna from nearby unaffected areas. Opportunistic species are the first to invade an area, followed by the establishment of a more stable population.

The adjustment of macrobenthic populations to perturbation is a natural event. Perturbations from storms cause faunal changes on the beach similar to manmade perturbations. Saloman and Naughton (1977) observed the effects of Hurricane Eloise at Panama City Beach, Florida, where severe beach erosion and property damage resulted. The beach benthic communities were modified. Oceanic species were washed inshore increasing species diversity along the beach. Simon and Dauer (1977) studied faunal damage caused by red tide at Tampa Bay, Florida. Benthic animal populations were destroyed, but their populations recolonized after about the 11 th month. In these studies recovery rate differed from one taxon to another. Therefore, care should be taken when using a single taxon to interpret an environmental perturbation.

Meiofauna recover very slowly from a major disturbance, perhaps due to their slow reproduction, limited ability to migrate, and their highly specialized adaptations to a restricted environment. Pequegnat (1975) and Rogers (1976) noted the slow recovery and lack of resiliency in meiobenthic organisms. Rogers and Darnell (1973) noted that meiobenthic populations had not completely recovered, even 18 years after a disturbance in a Texas estuary. However, Sherman and Coul1 (1980) found the recovery rapid (after one tidal cycle) for a minor disturbance. 
Most long-term studies have shown that moderate to complete recovery of motile animals will occur within less than a year, unless a sensitive resource is involved, e.g., coral reefs. Courtenay, et a1. (1972, 1980), Parr, Diener, and Lacy (1978), Reilly and Bellis (1978), and Holland, Chambers, and Blackman (1980) described motile fauna recovery following beach nourishment. Based on their studies it appears that motile fauna are generally not affected severely by beach nourishment. Studies have shown that motile animals generally leave an area of perturbance temporarily, but return when the disturbance ceases. Oliver, et al. (1977) observed that demersal fish moved into a disturbed area within the first day after disturbance. Courtenay, Hartig, and Loisel (1980) noted that lobsters, crabs, shrimp, and fish left a disturbed area, but reappeared 4 months after the disturbance ceased. The motile animals which have a stringent requirement for biological activities, i.e., habitat requirement or food source, are most likely to be affected. Sherk, $0^{\prime}$ Connor, and Neumann (1974) found that demersal fish are more tolerant to suspended solids and filter-feeding fish are least tolerant. Thus, based on these studies and observations during CERC studies in other coastal areas, it is concluded that fish fauna are usually not severely impacted by beach nourishment activities and will rapidly return to the impacted area after the disturbance ceases. An exception to this generalization would be species with a special habitat requirement or food source that is destroyed in the disturbance, e.g., the dusky jawfish on the Florida Atlantic coast.

\section{Corals.}

The recovery time for corals is directly proportional to the extent of initial reef damage. A reef that is badly torn and covered heavily with fine sediment, which kills the existing corals, may take a long time or may never recover.

Courtenay, et al. (1972, 1974) documented the initial effects of beach nourishment on corals in Florida. Reef-building corals exhibited damage from turbidity and sediment. In later surveys of the same area, Courtenay, Hartig, and Loisel (1980) and Marsh, et al. (1980) found maximum abundance and diversity of reef biota and corals after the nourishment area was left undisturbed for 7 years. These studies demonstrated that corals can recover from a disturbance if the damage is not too great. However, Bak (1978) concluded that recovery is generally slow and sometimes never occurs.

\section{Sea Turtles.}

Little information is available on the sea turtle's use of a beach following nourishment. Mann (1977) and Fletemeyer (1980) reported that sea turtles may be affected adversely by artificial changes in the beach substrate where they nest.

\section{EFFECTS OF BORROWING}

The most evident effect of offshore or nearshore borrowing is the mechanical disturbance of the substrate and subsequently the redeposition of suspended sediment and turbidity. Since varied assemblages of organisms reside in these 
areas, the effects on the local fauna may differ from species to species. Changes in existing physical and chemical features of the borrow areas will influence the short- and long-term effects on the fauna. Therefore, the overall impacts of borrowing operations may differ greatly between areas.

\section{Physical Effects.}

Dredging of borrow pits increases the suspended sediments and turbidity of the offshore water in the vicinity of the dredging operation. Courtenay, et al. (1974) and Maragos, et al. (1977) described sediments suspended during offshore dredging as generally localized and rapidly dissipating when dredging ceased. Maragos, et a1. (1977) noted that after dredging ceased the turbidity plume remained visible for several hours, but usually dissipated by the following morning. Factors that influence sediment spread and turbidities are water currents and water depth.

Another possible adverse effect associated with offshore dredging is the change in the bottom topography by creating deep borrow areas. Fine sediments may settle into the borrow pits, causing further changes in the composition of the bottom. Many species of marine animals which are found closely associated with specific sediment types may be excluded by sediment changes. Thorson (1964) observed that benthic fauna are sensitive to sediment composition and will not settle until suitable substrate is contacted. Undesirable substrate changes sometimes can be prevented by shallow dredging to minimize topographic and sediment changes and keeping the substrate in the photic zone (Thompson, 1973; Pisapia, 1974) or by selecting borrow sites in unstable areas that are under the influence of strong currents (Thompson, 1973; Saloman, Naughton, and Taylor, 1982). In unstable areas, benthic populations are generally low and are more adaptable to change. The borrow areas are also more likely to fill and return to near predredging conditions if there is adequate transport of sediments under the influence of strong currents, as observed at Panama City Beach, Florida (Saloman, Naughton, and Taylor, 1982; Culter and Mahadevan, 1982).

\section{Effects on Benthic Communities.}

The most serious impact of offshore dredging is the loss of major commercial species of benthic shellfish or the damage to coral reefs. These damages can be minimized by the proper selection of borrow areas and by precisely locating dredging equipment to avoid sensitive resources. Repopulation of the dredged area by benthic animals will depend on the magnitude of the disturbance, the new surface sediment, and the water quality of the borrow site. The borrow area will be recolonized by migration of organisms from adjacent areas; however, the population may not be of the same magnitude or species diversity as it was formally. The stability and bottom sediments at the site after dredging are major factors in determining species recolonization.

Several studies have assessed the faunal change in the vicinity of offshore borrow sites. Applied Biology, Inc. (1979) performed a qualitative and quantitative analysis of core samples from the vicinity of a borrow area in Duval County, Florida. The density of individuals and number of taxa were studied for 14 months. No clear differences in community parameters between control and affected transects were found. Statistical comparisons showed an occasional reduction in organisms from the vicinity of the borrow area. The authors suggested these differences were related to natural variability in the substrate. 
Saloman (1974) studied the benthic fauna of offshore borrow pits at Treasure Island, Florida, 3 years after dredging. The abundance and diversity of benthic animals were lower than undisturbed substrata in adjacent areas. The physical size of benthic animals from the borrow pits was very small compared to undisturbed areas. Sediment in the pits contained a high percentage of organic matter and hydrogen sulfide. The author concluded that the poor fauna of the offshore pits were due to siltation and low dissolved oxygen levels resulting in a poor-quality habitat. Taylor Biological Company (1978) also studied the borrow areas at Treasure Island, Florida, 4 years after dredging. It was concluded that all the borrow pits were slow in recovering.

Studies by Marsh, et al. (1978) indicated some beneficial aspects of offshore borrowing at Hillsboro Beach, Florida, done in 1972. Borrowing uncovered limestone rubble which improved the available habitat and resulted in more diverse and abundant macrobenthic and fish populations. The investigators concluded that borrowing created a new habitat for some organisms and attracted substrate sensitive larvae. Marsh, et a1. (1980) reported on a similar benthic study in Florida 7 years after a borrowing operation for beach nourishment. The area showed no apparent detrimental effect of the 1971 project; coral reefs damaged during early dredging apparently recovered.

More recently, Turbeville and Marsh (1982) reevaluated the long-term effects of borrowing at Hillsboro Beach, Florida. They noticed that species diversity was higher at the borrow site than at the control site and related this to uncovering a new habitat which attracted new species. This borrow area remained unfilled, had not accumulated organic material, and had good water quality 5 years after dredging. Gustafson (1972) also found enrichment of the fauna due to borrowing. He considered manmade disturbances as comparable to natural disturbances related to currents, winds, and tides. Saloman, Naughton, and Taylor (1982) noted that dredging at Panama City Beach, Florida, caused an immediate decline in benthic animals followed by a rapid population recovery. Culter and Mahadevan (1982) studied the same borrow area 7 years later. They concluded that, based on community analysis and sediment parameters, no significant differences were found between the borrow sites and surrounding areas.

Studies on meiobenthic animals have generally been on their life history and taxonomy and not related to beach nourishment operations. However, studies have been made on the effects of dredging on these organisms. Rogers and Darnel1 (1973) and Rogers (1976) reported on the effects of shell dredging in Texas. They sampled meiobenthic organisms at monthly intervals for a period of 8 months in dredge cuts. The researchers noticed that on recently dredged bottoms the meiofauna population was less than half of that of an undisturbed bottom. Dredge holes proved to be a poor environment for meiofaunal species. Similarly, Pequegnat (1975) reported on the response of meiobenthos to dredging. His major conclusion was that meiobenthic organisms respond negatively to low levels of environmental disturbance and would be expected to better reflect ecosystem degradation and recovery.

3. Effects on Motile Animals.

Conceivably, motile animals will be least affected by borrowing operations because of their ability to promptly escape any disturbed area. Research on the after effects of dredging indicates that minimum damage to motile fauna generally occurs. Occasionally, the productivity of a borrow area may actually 
increase and attract a greater variety and abundance of motile animals (Gustafson, 1972; Saloman, 1974; Maragos, et a1., 1977; Courtenay, Hartig, and Loise1, 1980; Holland, Chambers, and Blackman, 1980; Turbeville and Marsh, 1982). Courtenay, Hartig, and Loisel (1980) surveyed a borrow site off Hallandale, Florida, 7 years after dredging and found a remarkable increase in fish species except for the shallow-water burrowing dusky jawfish. The absence of this fish was attributed to habitat alteration. One of the earliest studies on the effects of dredging was recorded by Ingle (1952) for work done at Mobile Bay, Alabama. Here also, no effect on fish was observed in the region 23 to 46 meters from an active dredge.

Holland, Chambers, and Blackman (1980) reported an increase in number of fish at an offshore borrow site following dredging in the vicinity of Lido Key, Florida. Mean trawl catches increased after dredging ceased, which was interpreted as an increase in fish population. They related the increase in abundance of fish to the creation of new habitat and the increase in available food. Saloman (1974) observed fish fauna at Treasure Island, Florida. He noticed that the abundance and diversity of fishes were higher in the borrow areas after dredging ceased. Maragos, et al. (1977) noted that fish were attracted to a sand mining operation in Hawail. This was related to the uncovering and suspension of food that attracted the fish. Beneficial effect of dredging operations was also observed by Viosca (1958) who attributed the congregation of fishes near dredges in Louisiana to better availability of food and nutrients. Gustafson (1972) noted that borrow pits in San Francisco Bay, California, served as a haven for many game fish such as the striped bass (Roccus saxatilis).

4. Effects on Corals.

Lack of locomotion and sensitivity to reduced light renders these organisms susceptible to damage, especially when unplanned, careless dredging operations are conducted offshore. However, with proper planning, impacts on corals can be minimized in most cases. Courtenay, Hartig, and Loise1 (1980) and Marsh, et al. (1980) found high abundance and diversity of reef biota, corals, alcyonarians, and sponges 7 years after a dredging operation at Hallandale Beach, Florida. They concluded that in some cases corals can recover from dredging if the dredging impacts are held to a minimum.

Maragos, et al. (1977) conducted environmental surveys of an offshore mining delivery system in Hawaii. They surveyed abundance, distribution, and response of corals by diving observations and sampling before, during, and after a 2month field test. A "control" site was always surveyed on the basis of biological, physical, and geological similarities of the sand recovery sites. The most significant, immediate impact of the mining operation was due to the dragging of anchors and cables which collapsed adjacent reef rock and destroyed some mollusks and echinoderms. Maragos (1979) resurveyed the area 5 years after dredging and found some long-term impacts associated with erosion and scouring at the base of coral in the dredged area. Some of the coral slumped or tilted and some formed overhangs that broke off.

Bak (1978) noticed that during a dredging operation in the Antilles the light intensity decreased from about 30 percent surface illumination to 1 percent surface illumination at depths of 12 to 13 meters. Corals, which 
were shaded and unable to escape the sediment, lost their zooxanthellae and died. Additionally, the calcification rate in some corals was also suppressed.

Marszalek (1980) also studied the environmental impact of siltation (generated by dredging) on coral communities in Dade County, Florida. The stony corals were affected mostly by the accumulation of silt and turbidity. The same author recorded the results of dredging in 1978 near Haulover Cut, Miami Beach, Florida, where corals were surveyed after approximately 1 year. Soft corals and sponges showed no signs of damage, but hard corals exhibited bleaching and reduction in colony size. Marszalek attributed the effects on hard corals to the length of exposure to turbidity and sedimentation, rather than to just sedimentation. The lack of adverse effects on soft corals was perhaps due to their upright body, flexibility, and the current action removing the silt.

Spadoni (1978, 1979) reported on the effects of dredging on coral growth in connection with a beach nourishment project at Delray Beach, Florida. Five reef stations were monitored before, during, and after the beach nourishment project. Water and sedimentation samples were also collected and diver observations were made throughout the monitoring period to investigate the effects of the dredge cutterhead and positioning of the anchor on nearby corals. The investigator concluded that turbidity and sedimentation had no observable effects on reef corals. Iowever, reef damage did occur due to the dredge anchor and anchor cable dragging across the reef. The damage consisted of uprooted soft corals, fragmented sponges, and overturned or scarred coral heads. The most severely damaged area was that with the highest reef topography.

\section{Effects on Sea Turtles.}

The effect of borrowing on sea turtles is unknown because of the lack of information on this species. Little is also known about the young turtles that return to the ocean soon after their birth on the beaches. There is concern that the turtles w1ll be affected by dredging machinery at inshore and offshore borrow sites, especially because of their relatively slow locomotion, and they are known to hibernate in some deep navigational channels during the winter (Carr, Ogren, and Moven, 1980). Future borrowing projects involving sea turtles should be coordinated with U.S. Fish and Wildlife Service and National Marine Flsheries Service.

\section{Water and Sediment Quality.}

Nutrient release as a result of dredging does not appear to be a major problem offshore because of dispersal by currents and dilution. However, this may be a problem if nourishment material is taken from confined areas in the inshore. Changes in water and sediment quality at inshore and offshore borrow pits have been identified as potential problems. Deep borrow pits in stable areas can result in the accumulation of organic material and the stagnation of bottom water in the pits. Saloman (1974) and Taylor Piological Company (1978) observed this condition in offshore borrow pits at Treasure Island, Florida. Pisapia (1974), who reviewed the literature on the impacts of inshore dredge holes, reported that inshore dredge holes in areas where currents are low generally accumulate high concentrations of organic material and are considered poor-quality aquatic habitats. He also noted that warm waters in the dredged 
holes in the winter may attract fish, but low dissolved oxygen during the summer may result in low fish populations. The majority of the offshore borrow pits observed by CERC did not accumulate organics or have low dissolved oxygen. Saloman, Naughton, and Taylor (1982) and Culter and Mahadevan (1982) noted rapid filling of offshore borrow pits at Panama City Beach, Florida, and no water quality problems. Turbeville and Marsh (1982) noted that a borrow pit off Hillsboro Beach, Florida, had not filled with sediments after 5 years and water quality was generally good in the pit. Courtenay, et al. (1974) and Courtenay, Hartig, and Loisel (1980) observed no significant water quality problems at a borrow pit off Broward County, Florida. These contrasting conditions of the various borrow pits were related to the differing physical and chemical conditfons, i.e., currents, sediment movement, and water quality. This indicates a need for a thorough understanding of the area proposed as a borrow site before predicting impacts.

\section{FAUNAI, RECOVERY OF BORRON PITS}

Predictions of the recovery rate of animals in a borrow pit following dredging vary. The reason for the variation is that faunal recovery depends on many biotic and abiotic factors and their interaction.

\section{Benthic Communities.}

Repopulation of a dredged area by benthic animals will depend on the depth of the borrow pit, the new surface sediments, and the water quality of the borrow pit. Suitable borrow pits will be recolonized by migration of animals from adjacent areas; however, the reestablished population may not be the same abundance or species composition as before dredging.

Saloman (1974) observed benthic life in borrow pits dredged off Treasure Island, Florida, in a relatively stable environment (i.e., low waves and current). He found that the macrobenthic fauna in 3-year-old borrow pits were very sma11 in size and low in abundance and diversity compared to adjacent control areas. He hypothesized that as the benthic animals grew larger they sank into the soft sediments that had accumulated in the pits or died due to low dissolved oxygen and high levels of sulfide. Recovery was not apparent. Taylor Biological Company (1978) studied the same borrow pits off Treasure Island, Florida, 4 years after dredging and found the pits were filling with soft sediment and were in a slow state of recovery. They predicted it would take 10 years or more for the borrow pits to completely recover to predredging conditions.

In contrast, Saloman, Naughton, and Taylor (1982) studied borrow pits before dredging and for 1 year after dredging at Panama City Beach, Florida. They observed an immediate decline in the bottom communities followed by a rapid postconstruction recovery. Recovery was complete after about 1 year. Culter and Mahadevan (1982) studied the same borrow areas as Saloman, Naughton, and Taylor (1982) and concluded, based on benthic community analysis and sediment parameters, that there were no significant differences in benthic populations between the borrow and surrounding areas. However, they did conclude that because their control sites were in deeper water than the borrow sites and the benthic populations were different, the dredging effects were not completely clear. 
Applied Biology, Inc. (1979) studied offshore borrowing at Duval County, Florida, and found no significant differences in the number of species or density of macrobenthic animals between a borrow and control site 4 months after dredging was initiated. It was concluded that the sampling interval of the study may have exceeded the recovery period and the short-term impacts were not detected. Pisapia (1974) reviewed the literature on inshore dredge holes and concluded that recovery appears to be a function of water depth, sediment-size distribution, and prevailing physical and water quality conditions. The review indicated recovery is very slow to nonexistent.

Turbeville and Marsh (1982) surveyed a borrow pit off Broward County, Florida, and observed no long-term impacts as determined by number of species and faunal densities. They observed enhanced productivity within the borrow area compared to an adjacent control site. The borrow pit was still well defined and had a rubble limestone and sand bottom low in organic material 5 years after dredging.

Rogers and Darnell (1973) found that meiobenthos undergo a very low rate of population recovery following dredging. Some sites showed evidence of some recovery, but even after a period of 18 years the meiofauna had not recovered to former abundance. This study indicated that in the new dredge cuts ( 3 years old) the populations had recovered to about 32 percent of the original meiofauna population level. The older dredge cuts (18 years and older) recovered to about 80 percent of the original meiofauna population. Pequegnat (1975) also report incomplete recovery of meiofauna 7 years after dredging.

\section{Motile Animals.}

It appears that motile fauna are generally not affected adversely by dredging unless a major food source or habitat is removed or the quality of the area is severely degraded. Studies have shown that fish will leave an area of active dredging, but will return later (Courtenay, et a1., 1972, 1974; Harper, 1973; Oliver, et a1., 1977; Applied Biology, Inc., 1979; Courtenay, Hartig, and Loise1, 1980; Holland, Chambers, and Blackman, 1980). However, Courtenay, et al. (1972) noted that some motile animals were absent from a dredged area for up to 9 months. On the other hand, some motile animals are attracted to a dredged area as a new food source is made available (Maragos, et al., 1977). The sediment plume from the dredge also provides temporary protection to some motile animals (Harper, 1973). Therefore, recovery rate is variable and ranges from immediate for some species and up to a year or more for others, depending on the nature of the habitat damage.

\section{Corals.}

Courtenay, Hartig, and Loisel (1980) and Marsh, et al. (1980) documented the recovery of reef building corals from dredging after 7 years at Hallandale Beach, Florida. They concluded that coral recovery depends on the extent of reef damage.

Maragos (1979) observed long-term effects of dredging on reef coral in Hawail as a result of sand dredging. Five years after dredging it was observed that erosion at the base of coral resulted in its undermining (overturning, tilting colonies, or creating overhangs). He did find evidence of recovery in the form of small colonies of coral growing on rubble fragments. Maragos (1974) also reported that some reef sites subjected to pre-World War II dredging in 
Keauhou Bay have failed to recover after 30 years because of pollution, light limitation, sedimentation, and possibly competition from other benthic organisms.

In summary, it must be recognized that coral recovery is generally very slow and sometimes never occurs.

\section{Sea Turtles.}

The recovery of sea turtles will depend on the severity of the dredging impact. Hibernating sea turtles have been captured or killed by dredging (U.S. Army Engineer District, Jacksonville, 1981). However, normally turtles should react similarly to other motile animals and return to the area when dredging ceases.

\section{RECOMMENDATIONS}

The following recommendations are based on CERC-sponsored research and other literature. Physical, chemical, and biological conditions tend to vary from place to place; therefore, recommended procedures may not apply to all situations. However, for the benefit of the coastal manager these recommendations should be considered guidelines and used cautiously.

1. Beach Nourishment.

a. Biotic Surveys. Several investigators have suggested that animal communities be surveyed before, during, and after dredging and nourishment (Ingle, 1952; Thompson, 1973; Spadoni, 1978; Courtenay, Hartig, and Loisel, 1980; Marsh, et al., 1980). Such studies can be both qualitative and extensive depending on the intent of the study and resources available. This common survey approach is the least expensive and usually contributes the most toward avoiding unnecessary damage to valuable marine resources. As an absolute minimum a preproject base-line survey should be sponsored to identify and locate sensitive ecological resources, e.g., coral reefs, clam beds, and seagrass, in order to avoid these sensitive areas. See Hurme, Yancey, and Pullen (1979) for methodology and cost for such studies.

b. Optimum Time for Operation. Most CERC studies and others indicate that the best time biologically for beach nourishment and dredging is during the winter (Saloman, 1974; Oliver and Slattery, 1976; Reilly and Bellis, 1978; U.S. Army, Corps of Engineers, 1979). This is because the spawning season for most nearshore and beach fauna occurs between the spring and fall. The harmful effects of engineering activities are usually minimum during the winter, and larval recruitment is rot severely affected. Spadoni (1978) feels that summer would be better since the ocean is calmer during this period and allows rapid settlement of suspended sediments. However, based on CERC's experience and a review of the literature, construction during the winter season seems to be the best choice biologically. There would be a minimal effect on the adult and developmental stages of most nearshore and beach animals, and then fish and shellfish are less concentrated in the shallow beach zone during the winter season. It is, however, still necessary to determine if sensitive nonmotile resources are in the area during this period.

c. Composition of Nourishment Material. The composition of indigenous sediment at the deposition site should closely match with the dredged material 
(Thompson, 1973; Parr, Diener, and Lacy, 1978; Pearson and Riggs, 1981). The sediments should be low in pollutants. Minimum damage to the beach animals will occur when clean sand is placed on sandy substratum; the damage may be great to the beach animals if fine, organic-rich sediments are used. The vertical migration of infaunal animals may be inhibited when the particle size of borrowed material differs from the original sediments (Maurer, et a1., 1978).

To minimize siltation and consequently the potential anoxic conditions following beach nourishment, the percentage of fine sediment (less than 125 micrometers in size) should be kept to a minimum in the dredged material (Parr, Diener, and Lacy, 1978). Silt, if present in the material, will be rapidly moved offshore. It can be highly detrimental to corals and other beach and offshore benthic invertebrates, and therefore should be avoided as much as possible. Sedimentation can result in the reduction of species diversity. If a key species is affected adversely, the entire animal community of the area may be altered.

d. Locating Dredge Machinery. Damage to coral reefs has been caused by dragging of anchors or other equipment across a reef (Maragos, et al., 1977; Spadoni, 1979; Courtenay, Hartig, and Loisel, 1980). Therefore, the locating of all machinery should be done under the supervision of engineers-biologists to insure that damage to the reef areas is avoided. The dredge should be positioned within the designated borrow area and should not cross a live reef, clam bed, or other valuable resources. Mooring cables and anchors for the dredge should be in sand or another nonsensitive habitat to prevent unnecessary destruction to live corals, shellfish beds, and associated fish habitat.

e. Cutterhead Versus Suction Dredge. Cutterheads should not be used in the vicinity of live coral reefs or other light sensitive resources (Courtenay, et a1., 1975) unless barriers are established to separate the dredge site from the sensitive resource. Maragos, et a1. (1977) suggested using a suction dredge in the vicinity of live coral reefs to minimize suspension of sediments. Some similar type system without a cutterhead would be environmentally desirable, provided the discharge area is diked or otherwise isolated from the sensitive resource.

f. Sedimentation and Turbidity. Monitoring sedimentation and turbidity is important before, during, and after a project. Thorson (1964) showed that a reduction of light in the water will prevent or postpone larval settlement. High turbidities may affect larvae by delaying their final descent, subjecting them to increased predation. Sedimentation may change preferred bottom substrate preventing colonization or smothering some species.

g. Underwater Disposal. Nourishment material should be placed as close to shore as possible to insure the-least harm to the more stable, but less resilient nearshore population. Thompson (1973) and 01iver and S1attery (1976) suggested that organisms adapted to unstable bottom conditions tend to survive perturbations better than those in a more stable environment.

\section{Borrowing.}

The above recommendations also apply to borrowing operations. The selection of the borrow sites should be given special consideration, based on benthic surveys of several candidate sites to prevent unnecessary damage to benthic 
animals. Compatibility of the borrow material to the proposed beach is an important engineering and biological consideration, especially if inshore borrowing in areas of fine sediment is proposed. Rehandling of fill material between borrow areas and the beach should be avoided, particularly in the vicinity of live coral reefs or other sensitive resources. This practice tends to increase sediment suspension which may be detrimental to marine resources.

Consideration should be given to shallow dredging over large areas in low wave energy environments rather than deep dredging in a few locations (Thompson, 1973; Pisapia, 1974; Taylor Biological Company, 1978). Although the biological damage will be initially greater, recovery would be expected to be much quicker in the shallow dredge area.

Local directions in tidal flow and currents should be anticipated before initiating dredging, and the operation adjusted to prevent sediments from crossing live coral reefs or other sensitive resources. Dredging should be done during current conditions which will carry the suspended sediment toward deeper waters and away from coral reefs and other sensitive resources. Therefore, monitoring the direction of currents during open water dredging or disposal is recommended.

XII. SPECIAL RECOMMENDATIONS

\section{Coral Reefs.}

Damage to corals can be caused directly or indirectly. The direct effects of dredging involves physical damage by the cutterhead of the dredge, the anchor and cables dragging across a reef, or undermining of a reef by erosion following dredging. Indirect damage is done by suspended materials and turbidity which should be minimized as much as possible. The following special recommendations apply to coral reefs:

(a) Abundance and habits of fauna associated with corals should be studied before project features are developed and sited. A number of animals found closely associated with corals will be affected, inadvertently. This type of information will help in minimizing these impacts.

(b) Dredging in the immediate vicinity of live coral reefs should be avoided if possible. Courtenay, et al. (1980) observed damage to corals within a 220-meter radius of a borrow area at Hallandale Beach, Florida. Maragos (1979) studied the impacts of sand mining in Hawaii and concluded a buffer zone of 100 meters was sufficient to prevent damage to corals related to dredging. It appears, based on these studies, that a buffer zone should be established around live reefs to minimize the impacts of dredging. A zone of potential impact should be established based on field measurements of sediment and turbidity distribution around an operating dredge and the dredge positioned to minimize the impact on coral reefs.

(c) Where appropriate, dredging contracts should provide for periodic shutdowns of the dredge if suspended sediment flows toward live coral reefs or other sensitive resources and a new buffer zone established. 
(d) Dredges should be provided with adequate navigational equipment to maintain a known position in the vicinity of live coral reefs or other sensitive resources. This will help prevent any direct physical destruction of the reefs or the resources by the dredge and will assist in minimizing sedimentation impact by correctly positioning, the dredge.

(e) Recent aerial photos of reefs and the proposed borrow sites would be helpful in mapping the location of the reefs for positioning the dredge.

2. Sea Turtles.

The following are recommended to minimize the effects of beach nourishment operations on sea turtles:

(a) The composition of borrowed sand should match closely with the natural beach sand both physically and chemically. There is concern that sand compaction may result in higher nesting failure and nest destruction on a recently nourished beach because it is hard for the female to excavate new nests in compact sand (Fletemeyer, 1980). Hendrickson and Balasingham (1966) also suggested that sand particlesize differences on natural beaches influence site selection and nesting of the sea turtle.

(b) To avoid turtle-nesting season, nourishment should be done during the fall or winter (October to March).

(c) Turtle nests should be located if nourishment is to occur during their nesting season (spring or summer). Surveys should be conducted by turtle experts or personnel experienced in locating turtle nests. Nourishment should cease if nests with eggs are located. With the concurrence and proper permits from U.S. Fish and Wildlife Service, National Marine Fisheries Service, and State agencies, the turtle eggs may be relocated to a nearby undisturbed beach before initiating operations.

(d) Covering the upper beach vegetation should be avoided since the female turtles prefer nesting near dark vegetation (Mann, 1977).

(e) Since sea turtles nest only every 2 to 3 years, nesting records for a beach area would help establish the use of a particular beach by the turtles and would help in scheduling the nourishment operation.

(f) Consult with National Marine Fisheries Service regarding impacts of sea turtles seaward of the mean high water line.

\section{Fish.}

The beach and nearshore region is important for some species as feeding, spawning, and nursery habitats which may be affected adversely by siltation or direct burial under borrow material. Faunal surveys should include identification and mapping of these habitats so that they may be considered in planning a nourishment project. Generally, fishes are able to avoid undesirable 
areas and are not usually affected as much as nonmotile benthic organisms. However, the use of methods and techniques to reduce sedimentation and turbidity would be a wise precaution.

\section{Clam Beds.}

Damage to major clam beds may occur from borrowing and from covering by sediments. This can be minimized if the planner has knowledge of their distribution. Borrow sites should not be chosen which involve major clam beds. Also, sufficient distance from clam beds should be maintained so that suspended sediment will not be deposited on the beds or will not settle on the beds as a result of currents and tidal action. A similar determination of an impact zone as proposed for coral reefs, would probably be sufficient to prevent damage to clams. 
1. APPLIED BIOLOGY, INC., "Biological Studies Concerning Dredging and Beach Nourishment at Duval County, Florida, with a Review of Pertinent Literature," U.S. Army Engineer District, Jacksonville, Jacksonville, Fla., Sept. 1979.

2. BAK, R.P., "Lethal and Sublethal Effects of Dredging on Reef Corals," Marine Polzution Bulzetin, Vo1. 9, No. 1, Jan. 1978, pp. 14-16.

3. BOEHMER, R., and SLEIGHT, H., III, "Effects of Suspended Marine Sediment on Selected Commercially-Valuable Fish and Shellfish of Massachusetts," Proceedings of the Seventh Annual offshore Technology Conference, Vol. I, 1975, pp. 133-141.

4. CARR, A., OGREN, L., and MOVEN, C., "Apparent Hibernation by the Atlantic Loggerhead Turtle, Caretta Caretta, off Cape Canaveral, Florida, U.S.A.," Biological Consemation, Vol. 9, No. 1, 1980, pp. 7-14.

5. CLARK, M.B., "Distribution and Seasonal Dynamics of Animal Populations in San Diego Beaches," M.S. Thesis, San Diego State College, San Diego, Calif., 1969, pp. 136-154.

6. COURTEnAY, W.R., Jr., et a1., "Ecologica1 Monitoring of Two Beach Nourishment Projects in Broward County, Florida," Shore and Beach, Vo1. 40, No. 2, Oct. 1972, pp. 8-13.

7. COURTENAY, W.R., Jr., et al., "Ecological Monitoring of Beach Erosion Control Projects, Broward County, Florida, and Adjacent Areas," TM-41, U.S. Army, Corps of Engineers, Coastal Engineering Research Center, Fort Belvoir, Va., Feb. 1974.

8. COURTENAY, W.R., Jr., et al., "Environmental Assessment of offshore Reefs Off Miami Beach, Dade County, Florida," U.S. Army Engineer District, Jacksonville, Jacksonville, Fla., unpublished, 1975.

9. COURTENAY, W.R., Jr., HARTIG, B.C., and LOISEL, G.R., "Evaluation of Fish Populations Adjacent to Borrow Areas of Beach Nourishment Project at Hallandale (Broward County), Florida," Vol. 1, Ecological Evaluation of a Beach Nourishment Project at Hazlandale (Broward County), Florida, MR 80-1 (1), U.S. Army, Corps of Engineers, Coastal Engineering Research Center, Fort Belvoir, Va., Feb. 1980.

10. COX, J.L., "Sampling Variation in Sand Beach Littoral and Nearshore Meiofauna and Macrofauna," TP 76-14, U.S. Army, Corps of Engineers, Coastal Engineering Research Center, Fort Belvoir, Va., Sept. 1976.

11. CULTER, J.K., and MAHADEVAN, S., "Long-Term Effects of Beach Nourishment on the Benthic Fauna of Panama City Beach, Florida," MR 82-2, U.S. Army, Corps of Engineers, Coastal Engineering Research Center, Fort Belvoir, Va., Jan. 1982 . 
12. FENCHEL, T., "The Ecology of Marine Microbenthos IV. Structure and Function of the Benthic Ecosystem, its Chemical and Physical Factors and the Microfauna Communities with Special Reference to the Ciliated Protozoa," Ophelia, Vol. 6, 1969, pp. 1-182.

13. FletemEyeR, J., "Sea Turtle Monitoring Project," Cooperative Sea Turtle Monitoring Program, Nova University and Broward County Environmental Quality Board, Fla., 1978.

14. FLETEMEYER, J., "Sea Turtle Monitoring Project," Cooperative Sea Turtle Monitoring Program, Nova University and Broward County Environmental Quality Board, Fla., Nov. 1979.

15. FLETEMEYER, J., "Sea Turtle Monitoring Project," Cooperative Sea Turtle Monitoring Program, Nova University and Broward County Environmenta1 Quality Board, Fla., Nov. 1980.

16. GOLDBERG, W.M., "Some Aspects of the Ecology of the Reefs of Palm Beach County, Florida, with Emphasis on the Gorgonacea and their Bathymetric Distribution," M.S. Thesis, Florida Atlantic University, Boca Raton, Fla., 1970.

17. GUSTAFson, J.F., "Ecological Effects of Dredged Borrow Pits," World Dredging and Marine Construction, Vol. 8, No. 10, Sept. 1972, pp. 44-48.

18. HARPER, D.E., Jr., "Effects of Siltation and Turbidity on the Benthos and Nekton," Environmental Assessment of She 2 Dredging in San Antonio Bay, Texas, Vol. V, U.S. Army Engineer District, Galveston, Galveston, Tex., 1973, pp. 114-123.

19. HAYDEN, B., and DOLAN, R., "Impact of Beach Nourishment on Distribution of Emerita talpoida, the Common Mole Crab," Journal of the Waterways, Harbors, and Coastal Engineering Division, Vo1. 100, No. WW2, May 1974, pp. 123-132.

20. HENDRICKSON, J.R., and BALASINGHAM, E., "Nesting Beach Preferences of Malayan Sea Turtles," Bulletin of the National Museum Singapore, Vol. 33, No. 10, 1966, pp. 69-76.

21. HOLLAND, T.H., CHAMBERS, J.R., and BLACKMAN, R.R., "Effects of Dredging and Filling for Beach Erosion Control on Fishes in the Vicinity of Lido Key, Florida," U.S. Army Engineer District, Jacksonville, Jacksonville, Fla., unpublished, Mar. 1980.

22. HOLME, N.A., and McINTYRE, A.D., "Methods for the Study of Marine Benthos," Intemational Biological Programme, London, 1971.

23. HURME, A.K., YANCEY, R.M., and PULLEN, E.J., "Sampling Macroinvertebrates on High-Energy Sand Beaches," CETA 79-3, U.S. Army, Corps of Engineers, Coastal Engineering Research Center, Fort Belvoir, Va., Sept. 1979.

24. INGLE, R.M., "Studies on the Effects of Dredging Operations Upon Fish and Shellfish," Technical Series No. 5, State of Florida, Board of Conservation, Division of Oyster Culture, Tallahassee, Fla., Oct. 1952. 
25. LEBER, K.M., "Seasonal Community Dynamics of Macrobenthos on a High Energy Sand Beach in North Carolina," M.S. Thesis, East Carolina University, Greenville, N.C., Aug. 1977.

26. MANN, T.M., "Impact of Developed Coastline on Nesting and Hatching Sea Turtles on Southeastern Florida," M.S. Thesis, Florida Atlantic University, Boca Raton, Fla., Mar. 1977.

27. MARAGOS, J.E., "Coral Transplantation: A Method to Create, Preserve, and Manage Coral Reefs," Sea Grant Advisory Report UNIHI-SEAGRANT-AR-74-03, COMAR-14, University of Hawaii, Honolulu, Hawaii, Apr. 1974.

28. MARAGOS, J.E., "Environmental Surveys 5 Years After Cffshore Marine Sand Mining Operations at Keauhou Bay, Hawaii," U.S. Army Engineer Division, Pacific Ocean, Fort Shafter, Hawaii, unpublished, Oct. 1979.

29. MARAGOS, J.E., et al., "Environmental Surveys Before, During and After Offshore Marine Sand Mining Operations at Keauhou Bay, Hawaii," Sea Grant College Program, Working Paper No. 28, University of Hawaii, Honolulu, Hawaii, Dec. 1977.

30. MARSH, G.A., et a1., "Environmental Assessment of Nearshore Borrow Areas in Broward County, Florida," Final Report FAU-FIU, Joint Center for Environmental and Urban Problems, unpublished, Sept. 1978.

31. MARSH, G.A., et al., "Evaluation of Benthic Communities Adjacent to a Restored Beach, Hallandale (Broward County), Florida," Vol. II, Ecological Evaluation of a Beach Nourishment Project at HalZandale (Broward County), Florida, MR 80-1 (II), U.S. Army, Corps of Engineers, Coastal Engineering Research Center, Fort Belvoir, Va., Mar. 1980.

32. MARSZALEK, D.S., "Dredging on Marine Hardground Communities in the Vicinity of Haulover Cut, Miami Beach, Florida," Contract No. DACW17-77-C-0036, U.S. Army Engineer District, Jacksonville, Jacksonville, Fla., Dec. 1978.

33. MARSZALEK, D.S., "Dade County Beach Erosion Control and Hurricane Surge Protection Project," Contract No. DACW17-80-M-1773, U.S. Army Engineer District, Jacksonville, Jacksonville, Fla., Dec. 1980.

34. MAURER, D.L., et al., "Vertical Migration of Benthos in Simulated Dredged Material Overburdens," Literature Review, Technical Reprint D-78-35, U.S. Army Engineer Waterways Experiment Station, Vicksburg, Miss., 1978.

35. MAURER, D.L., et al., "Seasonal Fluctuations in Coastal Benthic Invertebrate Assemblages," Estuarine and Coastal Marine Science, Vo1. 8, 1979, pp. 181-193.

36. McLACHLAN, A., et a1., "Sand Beach Energetics: An Ecosystem Approach Towards a High Energy Interface," Estuarine and She If Science, Vo1. 13, 1981, pp. 11-25.

37. MENZIES, R.J., and ROWE, G.T., "The LUDS, A Large Undisturbed Bottom Sampler," Limnology and Oceanography, Vol. 13, No. 4, 1968, pp. 708-712. 
38. MODDE, T., "Growth and Residency of Juvenile Fishes Within the Surf Zone Habitat in the Gulf of Mexico," Gulf Research Reports, Vol. 6, No. 4, 1980, pp. 377-385.

39. O'CONNOR, J.M., NEUMANN, D.A., and SHERK, J.A., Jr., "Letha1 Effects of Suspended Sediments on Estuarine Fish," TP 76-20, U.S. Army, Corps of Engineers, Coastal Engineering Research Center, Fort Belvoir, Va., Dec. 1976.

40. OLIVER, J.S., and SLATTERY, P.N., "Effects of Dredging and Disposal on Some Benthos at Monterey Bay, California," TP 76-15, U.S. Army, Corps of Engineers, Coastal Engineering Research Center, Fort Belvoir, Va., Oct. 1976.

41. OLIVER, J.S., et a1., "Patterns of Succession in Benthic Infauna1 Communities Following Dredging and Dredged Material Disposal in Monterey Bay," Technical Report D-77-27, U.S. Army Engineer Waterways Experiment Station, Vicksburg, Miss., 1977.

42. PARR, T., DIENER, E., and LACY, S., "Effects of Beach Replenishment on the Nearshore Sand Fauna at Imperial Beach, California," MR 78-4, U.S. Army, Corps of Engineers, Coastal Engineering Research Center, Fort Belvoir, Va., Dec. 1978.

43. PEARSON, D.R., and RIGGS, S.R., "Relationship of Surface Sediments on the Lower Forebeach and Nearshore Shelf to Beach Nourishment at Wrightsville Beach, North Carolina," Shore and Beach, Vol. 49, No. 1, Jan. 1981, pp. 26-31.

44. PEQUEGNAT, W.E., "Meiobenthos Ecosystems as Indicators of the Effects of Dredging," Estuarine Research, Vol. 2, 1975, pp. 573-583.

45. PISAPIA, R.C., "Biological Implications of Dredge Holes," U.S. Fish and Wild1ife Service, Annapolis, Md., 1974.

46. REILIY, F.J., Jr., and BELLIS, V.J., "A Study of the Ecological Impact of Beach Nourishment with Dredged Materials on the Intertidal Zone," Technical Report No. 4, Institute for Coastal and Marine Resources, East Carolina University, Greenville, N.C., Sept. 1978.

47. REISH, D.J., "A Discussion of the Importance of the Screen Size in Washing Quantitative Marine Bottom Samples," Ecology, Vo1. 40, 1959, PP. 307-309.

48. ROGERS, R.M., "Distribution of Meiobenthic Organisms in San Antonio Bay in Relation to Season and Habitat Disturbance," She 27 Dredging and Its Influence on Gulf Coast Environments, A.H. Boume, ed., Gulf Publishing Co., Houston, Tex., 1976, pp. 92-108.

49. ROGERS, R.M., and DARNELL, R.M., "The Effects of Shell Dredging on the Distribution of Meiobenthic Organisms in San Antonio Bay, Texas," Vo1. III, Environmental Assessment of Shell Dredging in San Antonio Bay, Texas, U.S. Army Engineer District, Galveston, Galveston, Tex., 1973, pp. 159-167. 
50. SALOMAN, C.H., "Physical, Chemical, and Biological Characteristics of Nearshore Zone of Sandy Key, Florida, Prior to Beach Restoration," Final Report, U.S. Army, Corps of Engineers, Coastal Engineering Research Center, Fort Belvolr, Va., unpublished, 1974.

51. SALOMAN, C.H., and NAUGHTON, S.P., "Effects of Hurricane Eloise on the Benthic Fauna of Panama City Beach, Florida, USA," Marine Biology, Vol. 42, 1977, pp. 357-363.

52. SALOMAN, C.H., NAUGHTON, S.P., and TAYLOR, J.L., "Benthic Community Response to Dredging Borrow Pits, Panama City Beach, Florida," MR 82-3, U.S. Army, Corps of Engineers, Coastal Engineering Research Center, Fort Belvoir, Va., Mar. 1982.

53. SCHUBEL, J.R., and WANG, T.W., "The Effects of Suspended Sediment in Northern Chesapeake Bay," Powder Technology, Vo1. 6, 1973, pp. 9-16.

54. SHERK, J.A., O'CONNOR, J.M., and NEUMANN, D.A., "Effects of Suspended and Deposited Sediments on Estuarine Organisms, Phase II," Reference No. 74-02, National Research Institute, Solomons, Md., 1974.

55. SHERMAN, K.M., and COULL, B.C., "The Response of Melofauna to Sediment Disturbance," Journal of Experimental Marine Biology and Ecology, Vo1. 46, 1980, pp. 59-71.

56. SIMON, J.L., and DAUER, D.M., "Reestablishment of a Benthic Community Following Natural Defaunation," Ecology of Marine Benthos, 1st ed., Belle W. Baruch Institute for Marine Biology and Coastal Research, University of South Carolina Press, Columbia, S.C., 1977.

57. SPADONI, R.H., "Environmental Monitoring of the Beach Restoration Project for the City of Delray Beach, Florida," Beach Seminar 1978, No. 7, Oct. 1978, pp. 38-54.

58. SPADONI, R.H., "Reef Monitoring of the Delray Beach Erosion Project," Shore and Beach, Vo1. 47, No. 3, July 1979, pp. 12-16.

59. STERN, E., and STICKLE, W.B., "Effects of Turbidity and Suspended Material in Aquatic Environments," Literature Review, TR D-78-21, U.S. Army Engineer Waterways Experiment Station, Vicksburg, Miss., 1978.

60. TAYLOR BIOLOGICAL COMPANY, "Ecological Comparison of Beaches, Offshore Borrow Sites and Adjacent Bottom at Anna Maria Island and Treasure Island, Florida," Contract No. DACW17-78-M-1410, U.S. Army Engineer District, Jacksonville, Jacksonville, F1a., Dec. 1978.

61. THOMPSON, J.R., "Ecological Effects of offshore Dredging and Beach Nourishment: A Review," MP 1-73, U.S. Army, Corps of Engineers, Coastal Engineering Research Center, Fort Belvoir, Va., Jan. 1973.

62. THORSON, G., "Light as an Ecological Factor in the Dispersal and Settlement Larvae of Marine Bottom Invertebrates," Ophelia, Vol. 1, No. 1, 1964, pp. 167-208. 
63. TURBEVILlE, D.B., and MARSH, G.A., "Benthic Fauna of an offshore Borrow Area in Broward County, Florida," MR 82-1, U.S. Army, Corps of Engineers, Coastal Engineering Research Center, Fort Belvoir, Va., Jan. 1982.

64. TROPICAL BIOLOGICAL INDUSTRIES, "Environmental Impact Assessment of a Beach Restoration Project at South Seas Plantation, Captiva Island, Lee County, Florida," Final Report, South Seas Plantation, Captiva, Fla., Nov. 1979.

65. U.S. ARMY, CORPS OF ENGINEERS, "Effects of Dredging and Disposal on Aquatic Organisms," EM 1110-2-5031, Office of the Chief of Engineers, Washington, D.C., 1979.

66. U.S. ARMY ENGINEER DISTRICT, JACKSONVILLE, "Program Aim--Save Sea Turtles," The Drawbridge, Vol. 6, No. 8, Jacksonville, F1a., Aug. 1981.

67. VIOSCA, P., "Effects of Dredging Operations," 1956-1957 Biennial Report, Loulsiana Wildife and Fish Commission, 1958. 

BEACH NOURISHMENT

Fish

Turtle

Coral

Macrobenthic animals

BORROWING AND DREDGING

Fish

Cora1

Macrobenthic animals

Meiobenthic animals

RECOVERY AFTER NATURAL DISTURBANCE

RECOVERY AFTER ARTIFICIAL DISTURBANCE

Fish

Coral

Macrobenthos

Meiobenthic animals

TURBIDITY AND SUSPENDED MATERIAL
$6,7,9,21,42,46$

$13,14,15,26$

$6,7,9,31,57,58$

$1,5,6,7,11,19,31,34,42,46$, $50,60,64$
$6,7,8,9,17,18,21,24,29,41$, $50,63,67$

$2,6,7,8,9,16,27,28,29,31$, $32,33,57,58,65$

$1,11,17,30,31,32,33,50,52$, 60,63

$44,48,49,55$

51,56

\section{${ }^{1}$ See Literature Cited.}

$1,6,7,9,18,21,29,41,65$

$2,6,7,9,27,28,29,31,65$

$1,11,30,31,40,41,42,46,52$, $60,63,65$

$44,48,49,55$

$3,9,29,39,42,46,50,53,59,65$ 



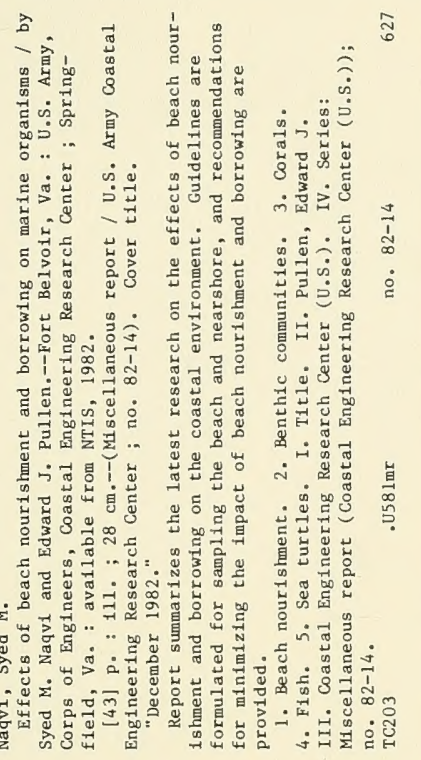

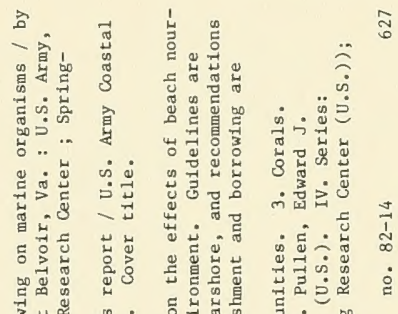

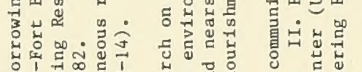

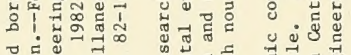

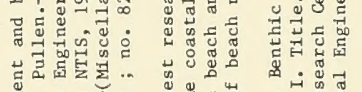

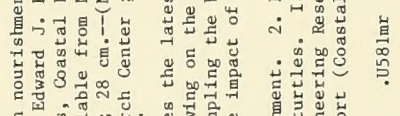

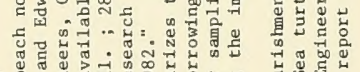

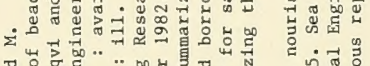

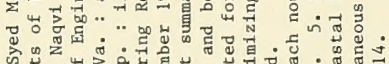
कि"

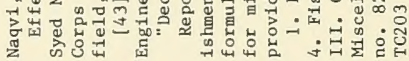

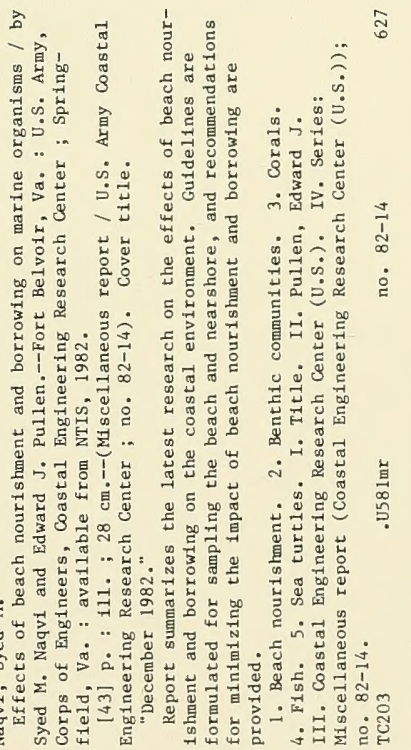

3

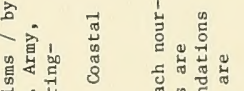

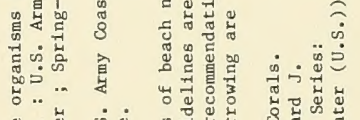

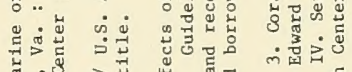

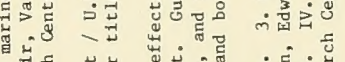

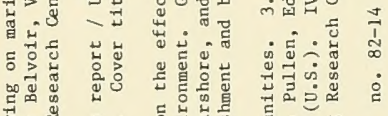

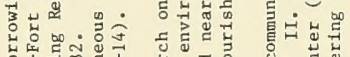

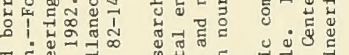

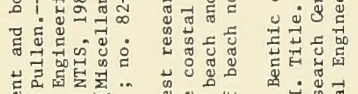

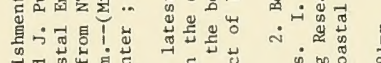

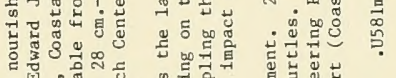

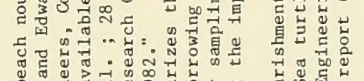

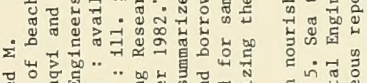

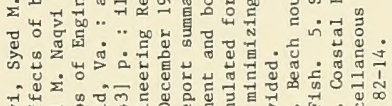

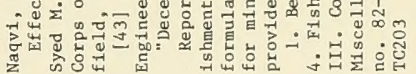



. 
